\title{
Nutrient input from the Colorado River to the northern Gulf of California is not required to maintain a productive pelagic ecosystem
}

\section{El aporte de nutrientes del río Colorado al norte del golfo de California no se requiere para mantener un ecosistema pelágico productivo}

\author{
Mario Rafael Ramírez-León ${ }^{1}$, Saúl Álvarez-Borrego ${ }^{1 *}$, Cuauhtémoc Turrent Thompson², \\ Gilberto Gaxiola Castro ${ }^{3}$, Gisela Heckel Dziendzielewski ${ }^{4}$ \\ ${ }^{1}$ Departamento de Ecología Marina, ${ }^{2}$ Departamento de Oceanografía Física, ${ }^{3}$ Departamento de Oceanografía \\ Biológica, ${ }^{4}$ Departamento de Biología de la Conservación, Centro de Investigación Científica y de Educación \\ Superior de Ensenada, Carretera Ensenada-Tijuana 3918, Ensenada, CP 22860, Baja California, México. \\ * Corresponding author. E-mail: alvarezb@cicese.mx
}

\begin{abstract}
The high phytoplankton production (PP) of the northern Gulf of California (NGC) supports a rich biodiversity and fisheries with high yields. The NGC is the habitat of the vaquita (Phocoena sinus), the cetacean most at risk of extinction in the world. The objective of this study is to demonstrate that the NGC is a healthy system at the level of primary producers despite the lack of nutrient input from the Colorado River, and that the small size of the vaquita population is not attributable the collapse of its pelagic ecosystem. Information derived from satellite sensors (CZCS, SeaWiFS, and Aqua-MODIS) was used to explore the possibility of a negative tendency in phytoplankton biomass and PP in the NGC during the last $\sim 35$ years. Temporal and spatial variations in sea surface temperature $\left(\mathrm{SST}_{\text {sat }}\right)$, chlorophyll concentration $\left(\mathrm{Chl}_{\text {sat }}\right)$, and PP were analyzed. Times series were generated for four coastal quadrants, two in the western part and two in the eastern part of the NGC. The NW quadrant covers the vaquita habitat, and it had higher $\mathrm{Ch}_{\text {sat }}$ and PP values than the others. This may be due to advection of turbid Upper Gulf waters into the NW quadrant. Semiannual and interannual changes in $\mathrm{Chl}_{\text {sat }}$ and PP occurred, but the seasonal signal was dominant in the whole region. $\mathrm{SST}_{\text {sat }}$ maxima occurred in August and September $\left(30-31^{\circ} \mathrm{C}\right)$ and minima in January and February $\left(16-17^{\circ} \mathrm{C}\right)$. Chl $\mathrm{sat}$ and PP maxima were recorded in March and April (2-3 $\mathrm{mg} \mathrm{m}^{-3}, 2-3 \mathrm{~g} \mathrm{C} \mathrm{m}^{-2}$ day ${ }^{-1}$, respectively) and minima in August and September $\left(0.2-0.9 \mathrm{mg} \mathrm{m}^{-3}, 0.5-1.1 \mathrm{~g} \mathrm{C} \mathrm{m}^{-2}\right.$ day $^{-1}$, respectively). These values indicate that the pelagic ecosystem of the NGC is very productive (mesotrophic in summer-autumn and eutrophic in winter-spring).
\end{abstract}

Key words: phytoplankton biomass, primary production, northern Gulf of California.

RESUMEN. La alta producción fitoplanctónica (PF) del norte del golfo de California (NGC) sustenta una gran biodiversidad y pesquerías con capturas elevadas. El NGC es el hábitat de la vaquita (Phocoena sinus), el cetáceo que se encuentra en mayor peligro de extinción en el mundo. El objetivo de este estudio es demostrar que el NGC es un sistema sano en el ámbito de los productores primarios a pesar de la falta del aporte de nutrientes del río Colorado, y que el tamaño pequeño de la población de la vaquita no se debe al colapso de su ecosistema pelágico. Se utilizó información satelital (CZCS, SeaWiFS y Aqua-MODIS) con el propósito de explorar la posibilidad de una tendencia negativa de la biomasa y producción fitoplanctónicas en el NGC en los últimos $\sim 35$ años. Se analizó la variación espaciotemporal de la temperatura superficial del mar $\left(\mathrm{TSM}_{\mathrm{sat}}\right)$, la concentración de clorofila $\left(\mathrm{Chl}_{\mathrm{sat}}\right)$ y PF. Se generaron series de tiempo para cuatro cuadrantes, dos en la parte occidental y dos en la parte oriental del NGC. El cuadrante noroccidental abarca el hábitat de la vaquita y presentó valores de Chl sat $_{\mathrm{y}} \mathrm{PF}$ más altos que el resto de los cuadrantes. Esto puede deberse a la advección de aguas turbias del Alto Golfo hacia el cuadrante noroccidental. Se observaron cambios semianuales e interanuales de $\mathrm{Ch}_{\mathrm{sat}} \mathrm{y} \mathrm{PF}$, pero los estacionales fueron dominantes en las cuatro localidades. Los máximos de TSM $\mathrm{sat}_{\mathrm{se}}$ registraron en agosto y septiembre $\left(30-31^{\circ} \mathrm{C}\right)$ y los mínimos en enero y febrero $\left(16-17{ }^{\circ} \mathrm{C}\right)$. Los máximos de Chl $1_{\text {sat }} \mathrm{y} P F$ se registraron en marzo y abril (2-3 $\mathrm{mg} \mathrm{m}^{-3}, 2-3 \mathrm{~g} \mathrm{C} \mathrm{m}^{-2}$ día $^{-1}$, respectivamente) y los mínimos en agosto y septiembre $\left(0.2-0.9 \mathrm{mg} \mathrm{m}^{-3}, 0.5-1.1 \mathrm{~g} \mathrm{C} \mathrm{m}^{-2}\right.$ día $^{-1}$, respectivamente). Estos valores de $\mathrm{Chl}_{\text {sat }} \mathrm{y}$ PF indican que el NGC es muy productivo (mesotrófico en verano-otoño y eutrófico en inviernoprimavera).

Palabras clave: biomasa fitoplanctónica, producción primaria, norte del golfo de California.

\section{INTRODUCTION}

The Gulf of California is one of the world's most productive marine ecosystems. It is an eutrophic system with an integrated phytoplankton production (PP) of $>1 \mathrm{~g} \mathrm{C} \mathrm{m}^{-2}$ day $^{-1}$ and in some places $>4 \mathrm{~g} \mathrm{C} \mathrm{m}^{-2}$ day $^{-1}$ (Álvarez-Borrego and

\section{INTRODUCCIÓN}

El golfo de California es uno de los ecosistemas marinos más productivos del planeta. Es un sistema eutrófico con una producción fitoplanctónica (PF) integrada de $>1 \mathrm{~g} \mathrm{C} \mathrm{m}^{-2} \mathrm{día}^{-1}$ $\mathrm{y}$ en algunos lugares $>4 \mathrm{~g} \mathrm{C} \mathrm{m}^{-2}$ día $^{-1}$ (Álvarez-Borrego y 
Lara-Lara 1991). Average PP for the whole gulf is $\sim 300 \mathrm{~g} \mathrm{C}$ $\mathrm{m}^{-2}$ year $^{-1}$ (Escalante et al. 2013). Considering the shallow isograms of $45 \mu \mathrm{mol} \mathrm{L} \mathrm{L}^{-1}$ dissolved oxygen, $2.5 \mu \mathrm{M}$ phosphate $\left(\mathrm{PO}_{4}\right)$, and $20 \mu \mathrm{M}$ nitrate $\left(\mathrm{NO}_{3}\right)$, with depths ranging from $50 \mathrm{~m}$ to little more than $100 \mathrm{~m}$ in the northern Gulf of California (NGC), the gulf's upwelling areas must be among the most productive. These nutrient-rich waters reach the euphotic zone by means of dynamic processes, mainly upwelling and mixing by tidal currents and winds. Surface nutrient concentrations in the NGC may be as high as $1.0 \mu \mathrm{M}$ $\mathrm{PO}_{4}, 4.0 \mu \mathrm{M} \mathrm{NO}_{3}$, and $18 \mu \mathrm{M} \mathrm{H}_{4} \mathrm{SiO}_{4}$ (Álvarez-Borrego et al. 1978).

The main natural fertilization mechanisms of the Gulf of California are water exchange with the Pacific, upwelling along the eastern coast, and mixing by tidal currents. Other phenomena, such as mesoscale meanders and eddies, also input nutrients to the euphotic zone, but their effect is more local. The net input of $\mathrm{NO}_{3}$ from the Pacific into the gulf has been estimated at $117 \times 10^{9} \mathrm{~mol} \mathrm{yr}^{-1}$ on average, and it is transported to the euphotic zone by upwelling, tidal mixing, etc. This input is much greater than the nutrient input by rivers, which is almost null because of the construction of dams and it has only very local effects (Álvarez-Borrego and Giles-Guzmán 2012).

Seasonality in the Gulf of California is well defined. There are two seasons: "winter", with northwesterly winds, from December through May; and "summer", with southeasterly winds, from July through October, with June and November as transition months. This seasonal cycle has a strong effect on the phytoplankton biomass and PP (HidalgoGonzález and Álvarez-Borrego 2004, Kahru et al. 2004). This is mainly because of the effect of winter upwelling on phytoplankton communities, which is much greater than that of summer upwelling. Surface chlorophyll concentrations (Chl) greater than $10 \mathrm{mg} \mathrm{m}^{-3}$ have been reported for some eastern regions of the gulf, and because of mesoscale eddy circulation these high concentrations are found across the gulf (Santamaría-del-Ángel et al. 1994a). On the other hand, summer upwelling off the peninsula has a weak impact because of the strong stratification caused by high surface temperatures, resulting in a small $\mathrm{Chl}$ increment (up to $\sim 0.5 \mathrm{mg} \mathrm{m}^{-3}$ ) (Santamaría-del-Ángel et al. 1999), and because surface flow direction is opposite that of the wind (Lluch-Cota 2000).

The NGC is the shallowest gulf region, with an average depth of $\sim 200 \mathrm{~m}$. It is one of the regions with highest PP, with $\mathrm{Chl}$ concentrations of up to $40 \mathrm{mg} \mathrm{m}^{-3}$, estimated from in situ sampling, and $>10 \mathrm{mg} \mathrm{m}^{-3}$, estimated from satellite data (Gendrop-Funes et al. 1978, Santamaría-del-Ángel et al. 1994a). In situ PP data (point estimates, with ${ }^{14} \mathrm{C}$ incubations) for the NGC are scarce, but some values are as high as $2.3 \mathrm{~g} \mathrm{C} \mathrm{m}^{-2}$ day $^{-1}$ (Álvarez-Borrego and Lara-Lara 1991). Hidalgo-González and Álvarez-Borrego (2004) used satellite data to estimate average PP values for the whole NGC of $1.61 \mathrm{~g} \mathrm{C} \mathrm{m}^{-2}$ day $^{-1}$ for winter and of $0.43 \mathrm{~g} \mathrm{C} \mathrm{m}^{-2}$ day $^{-1}$ for
Lara-Lara 1991). La PF promedio para todo el golfo es $\sim 300 \mathrm{~g} \mathrm{C} \mathrm{m}^{-2}$ año $^{-1}$ (Escalante et al. 2013). Considerando la poca profundidad de los isogramas como los de $45 \mu \mathrm{mol} \mathrm{L}^{-1}$ de oxígeno disuelto, $2.5 \mu \mathrm{M}$ de fosfato $\left(\mathrm{PO}_{4}\right)$ y $20 \mu \mathrm{M}$ de nitrato $\left(\mathrm{NO}_{3}\right)$, cuyas profundidades varían de $50 \mathrm{~m}$ a poco más de $100 \mathrm{~m}$ en el norte del golfo de California (NGC), las zonas de surgencia del golfo deben ser de las más productivas. Estas aguas ricas en nutrientes llegan a la zona eufótica por la dinámica física del golfo, principalmente surgencias y mezcla por corrientes de marea y vientos. Las concentraciones superficiales de nutrientes en el NGC pueden ser tan altas como $1.0 \mu \mathrm{M}$ de $\mathrm{PO}_{4}, 4.0 \mu \mathrm{M}$ de $\mathrm{NO}_{3}$ y $18 \mu \mathrm{M}$ de $\mathrm{H}_{4} \mathrm{SiO}_{4}$ (Álvarez-Borrego et al. 1978).

Los mecanismos naturales principales de fertilización del golfo de California son el intercambio de agua con el Pacífico, las surgencias a lo largo de la costa oriental y la mezcla debida a las corrientes de marea. Existen otros fenómenos, como los meandros y remolinos de mesoescala, que también aportan nutrientes a la zona eufótica, pero su efecto es más local. Se estima que el aporte neto de $\mathrm{NO}_{3}$ del Pacífico al golfo es $117 \times 10^{9} \mathrm{~mol} \mathrm{año}^{-1}$ en promedio, y este aporte llega hasta la capa eufótica por medio de fenómenos como surgencias, mezcla por mareas, etc. Este aporte es mucho mayor que el aporte de nutrientes de los ríos. Este último es casi nulo debido al represamiento de los ríos, y en su caso sólo tiene efectos locales (Álvarez-Borrego y Giles-Guzmán 2012).

La estacionalidad en el golfo de California está bien definida. Se distinguen dos épocas: "invierno", con vientos del noroeste, abarca los meses de diciembre a mayo; y "verano", con vientos del sureste, abarca los meses de julio a octubre, con junio y noviembre como meses de transición (HidalgoGonzález y Álvarez-Borrego 2004). Este ciclo estacional tiene una influencia fuerte en la variación de la biomasa fitoplanctónica y PF (Hidalgo-González y Álvarez-Borrego 2004, Kahru et al. 2004). Esto se debe principalmente al efecto que tienen las surgencias de invierno sobre las comunidades fitoplanctónicas, que es mucho mayor que el de las surgencias de verano. Se han registrado concentraciones de clorofila (Chl) de más de $10 \mathrm{mg} \mathrm{m}^{-3}$ en invierno en algunas regiones orientales del golfo, y debido a la circulación de giros de mesoescala, estas concentraciones altas se extienden a lo ancho del golfo (Santamaría-del-Ángel et al. 1994a). Por otro lado, las surgencias de verano frente a la costa de la península tienen un impacto débil debido a la estratificación fuerte originada por las temperaturas superficiales altas, lo cual genera un incremento pequeño de $\mathrm{Chl}$ (hasta $\sim 0.5 \mathrm{mg} \mathrm{m}^{-3}$ ), y debido a la circulación superficial contraria a la dirección en la que sopla el viento (Santamaría-del-Ángel et al. 1999, Lluch-Cota 2000).

El NGC es la región más somera del golfo con una profundidad promedio de $200 \mathrm{~m}$, aproximadamente. Es una de las regiones con mayor PF, con Chl de hasta $40 \mathrm{mg} \mathrm{m}^{-3}$ 
summer. The NGC serves as a reproduction and nursery ground for many invertebrate species, marine mammals, and birds. Its high PP sustains a rich biodiversity consisting of 544 vertebrate and 2258 invertebrate species, of which $\sim 147$ are endemic; all together, they represent $47 \%$ of the diversity of the entire Gulf of California (Brusca et al. 2005).

Sea bass, sardine, and several shrimp species are the main fishery resources of the NGC. The shrimp trawl fishery is one of the most profitable (Cisneros-Mata 2010); however, this fishery has been responsible for the overharvesting of several species because the shrimp bycatch is $\sim 10 \mathrm{t}$ for each ton of captured shrimp. This bycatch is mainly composed of juveniles of several species. The shrimp fishery has decreased the biodiversity of benthic communities and it has modified the substrate (Carvajal et al. 2010).

The Biosphere Reserve of the Upper Gulf of California and Colorado River Delta was established by federal decree in 1993. Its original purpose was to protect the vaquita (Phocoena sinus) but a large fraction of its habitat falls outside the reserve. This species is in critical danger. The vaquita's distribution is restricted to $4000 \mathrm{~km}^{2}$ in the northwestern NGC (around $30^{\circ} 45^{\prime} \mathrm{N}, 114^{\circ} 20^{\prime} \mathrm{W}$ ) (Rojas-Bracho et al. 2006). A refuge area for the vaquita of $1263 \mathrm{~km}^{2}$ was decreed in 2005, but it was extended to $11,000 \mathrm{~km}^{2}$ in April 2015.

Over the past three decades controversy has arisen between the fisheries and conservation sectors regarding the management and conservation of the vaquita, because of the ecological problems generated by the fishing activities in this region (Brusca et al. 2005). The hypothesis of the fisheries sector is that the vaquita population has decreased because the lack of freshwater from the Colorado River has negatively impacted the NGC's ecosystem. This hypothesis establishes that with no freshwater there is no nutrient input into the NGC and PP has decreased (Galindo-Bect et al. 2000), causing the pelagic ecosystem to collapse. Yet, there is no proof that nutrient concentrations have diminished significantly, there are no data showing that PP has decreased, and apparently the low nutrient input is not a risk factor for the vaquita in the short term. On the other hand, it has been documented that the vaquita population decline is mainly caused by fishing activities (Rojas-Bracho and Taylor 1999).

The objective of this contribution is to show that the vaquita habitat, and the whole $\mathrm{NGC}$, is a healthy ecosystem in relation to its primary producers $\left(\mathrm{Chl}>1 \mathrm{mg} \mathrm{m}^{-3}\right)$ and that there is no collapse of the pelagic ecosystem because of the lack of nutrients previously supplied by the Colorado River. Several contributions based on satellite data have described the spatial and temporal variation in phytoplankton biomass and PP of the Gulf of California (Hidalgo-González and Álvarez-Borrego 2004, Herrera-Cervantes et al. 2010, and others cited therein); however, there are no studies describing the details of the large-scale spatial and temporal variation in phytoplankton biomass and PP (synoptic studies) for the NGC. In this contribution we aim to answer the following según mediciones de muestreos in situ, y $>10 \mathrm{mg} \mathrm{m}^{-3}$ según estimaciones con datos de satélite (Gendrop-Funes et al. 1978, Santamaría-del-Ángel et al. 1994a). Los datos in situ de PF (puntuales, con incubaciones con ${ }^{14} \mathrm{C}$ ) del $\mathrm{NGC}$ son escasos, pero con valores altos de hasta $2.3 \mathrm{~g} \mathrm{C} \mathrm{m}^{-2}$ día $^{-1}$ (Álvarez-Borrego y Lara-Lara 1991). Hidalgo-González y Álvarez-Borrego (2004) reportaron una PF promedio, calculada para todo el NGC con base en datos de satélite, de $1.61 \mathrm{~g}$ $\mathrm{C} \mathrm{m}^{-2}$ día $^{-1}$ para invierno y de $0.43 \mathrm{~g} \mathrm{C} \mathrm{m}^{-2}$ día $^{-1}$ para verano. El NGC sirve como lugar de reproducción y crianza para muchas especies de invertebrados, peces, mamíferos marinos y aves. Su PF alta sustenta una gran diversidad biológica con 544 especies de vertebrados y 2258 de invertebrados, de las cuales $\sim 147$ son endémicas; en conjunto, estas especies representan el $47 \%$ de la diversidad de todo el golfo de California (Brusca et al. 2005).

Entre los principales recursos pesqueros del NGC se encuentran la corvina, la sardina y distintas especies de camarón. La pesquería de arrastre del camarón es una de las más remunerables (Cisneros-Mata 2010); sin embargo, ha llevado a varias especies a ser sobreexplotadas. Esto se debe a que la fauna acompañante del camarón es $\sim 10 \mathrm{t}$ por cada tonelada de camarón capturado, e incluye principalmente juveniles de especies diversas. La pesquería de camarón ha disminuido la biodiversidad de las comunidades bentónicas y ha modificado la estructura del sustrato (Carvajal et al. 2010).

La Reserva de la Biosfera del Alto Golfo de California y Delta del Río Colorado se estableció por decreto federal en 1993. Originalmente pretendía proteger la vaquita marina (Phocoena sinus), pero una porción grande del hábitat de esta especie quedó fuera de la reserva. La vaquita se encuentra en peligro crítico. La distribución de la vaquita se restringe a $4000 \mathrm{~km}^{2}$ en la parte noroeste del NGC (alrededor de $30^{\circ} 45^{\prime} \mathrm{N}, 114^{\circ} 20^{\prime} \mathrm{W}$ ) (Rojas-Bracho et al. 2006). En 2005 se decretó un área de refugio para la vaquita de $1263 \mathrm{~km}^{2}$, y en abril de 2015 se decretó una ampliación para quedar en $11,000 \mathrm{~km}^{2}$.

Durante las últimas tres décadas ha habido una controversia en torno al manejo y conservación de la vaquita entre el sector pesquero y el de la conservación, por los problemas ecológicos que la actividad pesquera ha generado en esta región (Brusca et al. 2005). El sector pesquero maneja la hipótesis de que la población de la vaquita ha disminuido debido a la alteración del ecosistema del NGC por el cese del aporte de agua dulce del río Colorado. La hipótesis establece que al no existir este aporte no entran nutrientes al NGC y, por lo tanto, la PF ha disminuido (Galindo-Bect et al. 2000), lo cual ha ocasionado que el sistema pelágico se haya deteriorado. Sin embargo, no se ha demostrado que los niveles de nutrientes en el NGC hayan disminuido significativamente, ni que la PF haya disminuido, y aparentemente el cese del aporte de nutrientes no es un factor de riesgo para la vaquita a 
question: Based on the phytoplankton biomass and PP, is the pelagic ecosystem of the NGC healthy enough to sustain populations of marine mammals such as the vaquita?

\section{MATERIALS AND METHODS}

\section{Satellite data}

The satellite-derived $\mathrm{Chl} a\left(\mathrm{Chl}_{\mathrm{sat}}\right)$ is the $\mathrm{Chl}_{(\mathrm{z})}$ averaged for the first optical depth (the upper $22 \%$ of the euphotic zone), weighted by the irradiance attenuated twice (when the light is going down and when it is back-scattered up) (Kirk 1994). Monthly composites of day sea surface temperature (SST) and $\mathrm{Chl}_{\text {sat }}$ were obtained from the NASA website (http://oceancolor.gsfc.nasa.gov/) (level 3 standard mapped image products, $9 \times 9 \mathrm{~km}^{2}$ pixel size). PP monthly composites were retrieved as a standard product from the Oregon State University (OSU) Ocean Productivity site (http:// www.science.oregonstate.edu/ocean.productivity/index.php). This website provides PP already calculated with the original Behrenfeld and Falkowsky (1997) vertically generalized production model (VGPM). The VGPM is a non-spectral, homogeneous-biomass vertical distribution, vertically integrated production model.

Data from the CZCS, SeaWiFS, and Aqua-MODIS sensors were used. $\mathrm{Ch}_{\text {sat }}$ data were retrieved from all three sensors, but SST and PP were only derived from aqua-MODIS. Satellite imagery was processed with software provided by NASA (SeaWIFS Data Analysis System, SeaDAS 7.0.2) (http://oceancolor.gsfc.nasa.gov/seadas/). To study possible spatial differences of water properties (SST, $\mathrm{Chl}_{\text {sat }}$, and PP), four quadrants were chosen, two in the western (NW and SW) and two in the eastern (NE and SE) parts of the NGC. Each quadrant covered $2025 \mathrm{~km}^{2}$ (5 pixels of $9 \times 9 \mathrm{~km}^{2}$ on each side; a total of 25 pixels). The NW quadrant coincides approximately with the vaquita habitat. Also, a quadrant at Guaymas Basin was chosen, where there should be no effect of the lack of river water and nutrient input, to compare the temporal behavior of $\mathrm{Chl}_{\text {sat }}$ data from the three sensors (fig. 1).

Time series of SST, $\mathrm{Chl}_{\mathrm{sat}}$, and PP were generated for each quadrant (averages of 25 values per quadrant, per monthly composite). The study period for SST was July 2002 to June 2013, with Aqua-MODIS data. Three time series were generated for Chl $\mathrm{s}_{\mathrm{sat}}$ : November 1978 to June 1986, with CZCS data; September 1997 to December 2010, with SeaWiFS data; and July 2002 to June 2013, with Aqua-MODIS data. The study period for PP was July 2002 to June 2013, with Aqua-MODIS data. The spectral analysis of time series was performed using Welch's (1967) periodograms method . To apply this method, low frequencies (interannual variations) were eliminated to filter long-term variation tendencies. As a first approximation to the climatology, an "average year" was generated for each variable and for each quadrant. In the case of $\mathrm{Chl}_{\mathrm{sa}}$, this was also done for each sensor. To do this, data corto plazo. Por otra parte, se ha documentado que la disminución de la población de la vaquita es causada principalmente por la actividad pesquera (Rojas-Bracho y Taylor 1999).

El objetivo de este trabajo es demostrar que el hábitat de la vaquita marina, y todo el NGC, es un ecosistema sano con relación a los productores primarios $\left(\mathrm{Chl}>1 \mathrm{mg} \mathrm{m}^{-3}\right)$ y que no existe un colapso del ecosistema pelágico por falta de nutrientes que provenían del río Colorado. Varios trabajos basados en datos de satélite han descrito la variación espacio-temporal de la biomasa fitoplanctónica y PF del golfo de California (Hidalgo-González y Álvarez-Borrego 2004, Herrera-Cervantes et al. 2010, y otros citados en estos trabajos); sin embargo, no existen estudios que detallen la variabilidad espaciotemporal de la biomasa fitoplanctónica y PF a grandes escalas (estudio sinóptico) para el NGC. La pregunta a responder en esta contribución es la siguiente: Con base en la biomasa y producción fitoplanctónicas, ¿es el ecosistema pelágico del NGC suficientemente saludable para sostener poblaciones de mamíferos marinos como la vaquita?

\section{MATERIALES Y MÉTODOS}

\section{Datos de satélite}

La Chl $a$ derivada de satélite $\left(\mathrm{Chl}_{\text {sat }}\right)$ es la $\mathrm{Chl}_{z}$ promediada para la primera profundidad óptica (el $22 \%$ superior de la zona eufótica), ponderada por la irradiancia atenuada dos veces (cuando la luz va hacia abajo y cuando se retro-esparce hacia arriba) (Kirk 1994). Se utilizaron composiciones mensuales de la temperatura superficial del mar (TSM) diurna, $\mathrm{Ch}_{\text {sat }}$ y PF. Las composiciones mensuales de TSM y $\mathrm{Chl}_{\text {sat }}$ se obtuvieron del sitio web de la NASA (http://oceancolor.gsfc.nasa.gov/) (nivel 3 de procesamiento, tamaño de pixel de $9 \times 9 \mathrm{~km}^{2}$ ). Las composiciones mensuales de PF se adquirieron como producto estándar del sitio web del Ocean Net Primary Productivity (http://www.science.oregonstate.edu/ocean.productivity/index.php) de la Universidad Estatal de Oregón (OSU, por sus siglas en inglés). Este sitio provee PF ya calculada con el modelo de producción vertical generalizado (VGPM) de Behrenfeld y Falkowsky (1997). El VGPM es un modelo de producción no espectral, con distribución vertical homogénea de biomasa fitoplanctónica, e integrado verticalmente.

Se utilizaron datos de los sensores CZCS, SeaWiFS y Aqua-MODIS. Los datos de $\mathrm{Chl}_{\text {sat }}$ se derivaron de los tres sensores, pero los de TSM y PF se derivaron sólo del aquaMODIS. Las imágenes de satélite fueron procesadas con el programa proporcionado por la NASA (SeaWIFS Data Analysis System, SeaDAS 7.0.2) (http://oceancolor.gsfc.nasa.gov/ seadas/). Para estudiar posibles diferencias espaciales de las propiedades del agua (TSM, $\mathrm{Ch}_{\text {sat }} \mathrm{y} \mathrm{PF}$ ), se escogieron 


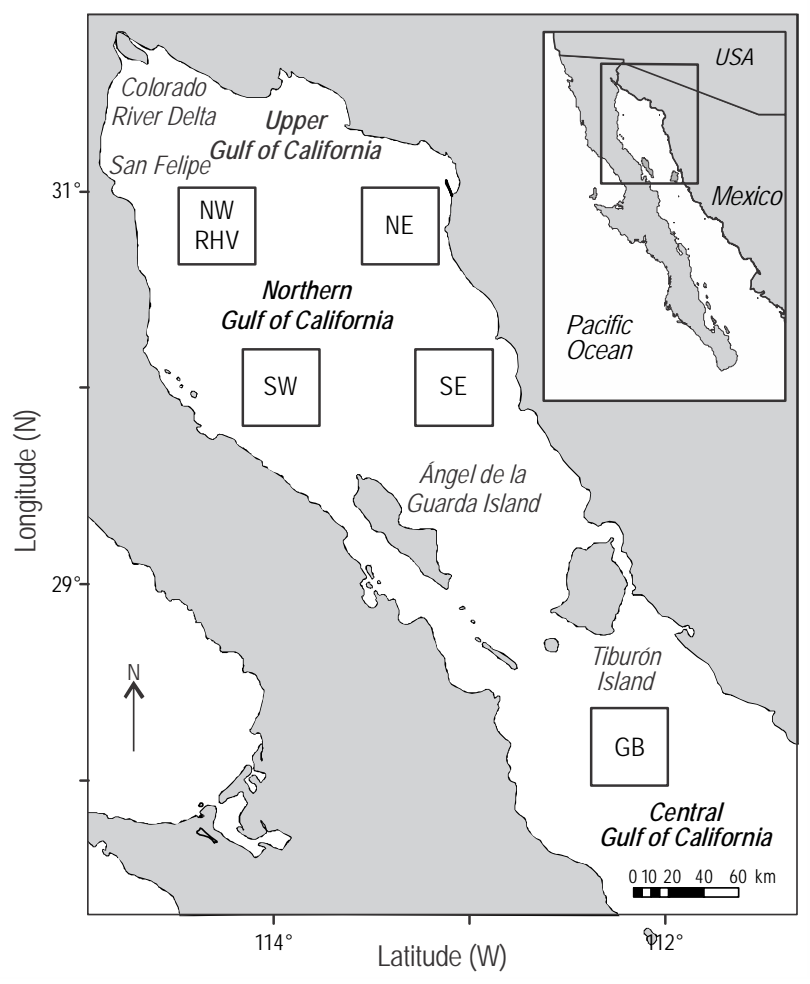

Figure 1. Study area. Location of the four quadrants in the northern Gulf of California and of the Guaymas Basin (GB) quadrant. RHV, vaquita habitat range.

Figura 1. Área de estudio. Localidades de los cuatro cuadrantes en el norte del golfo de California y el de la cuenca de Guaymas (GB). RHV, hábitat de la vaquita marina.

from all Januaries were taken to obtain the "average January" for each variable and for each quadrant, and so on for all months. To generate a true climatology, data from at least 30 years are needed.

\section{Models to estimate phytoplankton productivity}

Kahru et al. (2009) and Álvarez-Molina et al. (2013) reported that the PP values from OSU's Ocean Productivity page $\left(\mathrm{PP}_{\mathrm{OSU}}\right)$ calculated with the VGPM are overestimated by as much as $50 \%$. To corroborate this, 40 Aqua-MODIS $\mathrm{Chl}_{\text {sat }}$ data were chosen at random (10 from each quadrant), and independent PP estimates were performed to compare them with $\mathrm{PP}_{\mathrm{Osu}}$. Platt et al.'s (1991) model, as modified by Hidalgo-González and Álvarez-Borrego (2004), was used to calculate these independent PP values. Platt et al.'s (1991) model considers a non-homogeneous Chl vertical distribution that takes into account the deep Chl maximum. HidalgoGonzález and Álvarez-Borrego (2004) applied this model to case I waters $\left(\mathrm{Chl}<1.5 \mathrm{mg} \mathrm{m}^{-3}\right)$ and case II waters $\left(\mathrm{Chl}>1.5 \mathrm{mg} \mathrm{m}^{-3}\right)$. For case II waters, Platt et al.'s (1991) original model was used. This is a non-spectral model that estimates PP without taking into consideration the change of light quality with depth (eq. 1): cuatro cuadrantes en el NGC, dos en la parte occidental (NW y SW) y dos en la parte oriental (NE y SE). Cada cuadrante cubrió $2025 \mathrm{~km}^{2}$ (5 pixeles de $9 \times 9 \mathrm{~km}^{2}$ por lado; un total de 25 pixeles). El cuadrante NW coincide aproximadamente con el hábitat de la vaquita. Además, se escogió un cuadrante en la cuenca de Guaymas, donde no se esperaba el efecto de la falta de aporte de agua de ríos y sus nutrientes, para comparar el comportamiento temporal de los datos de $\mathrm{Chl}_{\text {sat }}$ de los tres sensores (fig. 1).

Se generaron series de tiempo de los promedios de TSM, $\mathrm{Chl}_{\text {sat }}$ y PF para cada cuadrante (promedios de 25 valores por cuadrante, por composición mensual). El periodo de estudio para TSM fue de julio de 2002 a junio de 2013, con datos del Aqua-MODIS. Se generaron tres series de tiempo para $\mathrm{Chl}_{\text {sat }}$ : noviembre de 1978 a junio de 1986, con datos del CZCS; septiembre de 1997 a diciembre de 2010, con datos del SeaWiFS; y julio de 2002 a junio de 2013, con datos del Aqua-MODIS. El periodo de estudio para PF fue de julio de 2002 a junio de 2013, con datos del Aqua-MODIS. Se realizó un análisis espectral de las series de tiempo con el método de periodogramas de Welch (1967). Para esto, se eliminaron las bajas frecuencias (variación interanual) para quitar las tendencias de periodo largo. Como una primera aproximación a la climatología, se generó un "año promedio" para cada variable y para cada cuadrante; en el caso de $\mathrm{Chl}_{\text {sat, }}$ esto también se hizo para cada sensor. Para hacer esto, se promediaron todos los datos de los eneros para obtener el "enero promedio", y así sucesivamente con el resto de los meses, para cada variable y para cada cuadrante. Para generar una climatología verdadera se requieren datos de por lo menos 30 años.

\section{Modelos para estimar la producción fitoplanctónica}

Kahru et al. (2009) y Álvarez-Molina et al. (2013) documentaron que los valores de PF calculados con el VGPM (PF de la página Ocean Productivity de la $\mathrm{OSU}, \mathrm{PF}_{\mathrm{OSU}}$ ) están sobreestimados hasta en un $50 \%$. Para corroborar esto, se eligieron al azar 40 datos de $\mathrm{Chl}_{\text {sat }}$ del Aqua-MODIS (10 por cada cuadrante), y se realizaron cálculos independientes de PF para hacer comparaciones con los de la página de la OSU. Para los cálculos independientes de PF, se siguió el modelo propuesto por Platt et al. (1991), con modificaciones de Hidalgo-González y Álvarez-Borrego (2004). El modelo de Platt et al. (1991) considera un perfil de Chl no homogéneo que toma en cuenta el máximo profundo de Chl. HidalgoGonzález y Álvarez-Borrego (2004) aplicaron este modelo para aguas caso I $\left(\mathrm{Chl}<1.5 \mathrm{mg} \mathrm{m}^{-3}\right)$ y para aguas caso II $\left(\mathrm{Chl}>1.5 \mathrm{mg} \mathrm{m}^{-3}\right)$. Para aguas caso II, se utilizó el modelo original de Platt et al. (1991). Este es un modelo no espectral que estima la PF sin tomar en cuenta el cambio de calidad de la luz con la profundidad (ec. 1): 


$$
P P_{(z)}=\left[P_{m_{(z)}}^{*} C h l_{z} \alpha_{P A R_{(z)}}^{*} P A R_{z}\right] \times\left[\left(P_{m_{(z)}}^{*}\right)^{2}+\left(P A R_{z} \alpha_{P A R_{(z)}}^{*}\right)^{2}\right]^{-0.5}
$$

where $P_{m_{(z)}}^{*}$ is the maximum photosynthetic rate at optimum

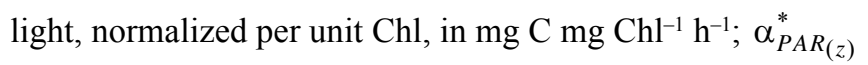
is the initial slope of the photosynthesis-irradiance relationship (P-E curve), in mg C mg Chl ${ }^{-1} \mathrm{~h}^{-1}$ ( $\mu$ mol quanta $\mathrm{m}^{-2}$ $\left.\mathrm{s}^{-1}\right)^{-1}$; and PAR is the photosynthetically active radiation, in $\mu$ mol quanta $\mathrm{m}^{-2} \mathrm{~s}^{-1}$. Integration of equation 1 with depth provides $\mathrm{PP}_{\mathrm{PS}}$. For case I waters, the model was modified with Giles-Guzmán and Álvarez-Borrego's (2000) expression for the chlorophyll-specific absorption coefficient of phytoplankton $\left(a_{p h(z, C h l)}^{*}\right)$. This modification corrects the initial slope of the photosynthesis-irradiance relationship for the spectral distribution of in situ scalar PAR and for the package effect. The expression $43.2 \phi_{\max } a_{p h_{(z, C h l)}^{*}}^{*}$ is used instead of the initial slope $\alpha_{P A R_{(z)}}^{*}$ (eq. 2). The factor 43.2 converts mol C to $\mathrm{mg} \mathrm{C}$, seconds to hours, and mol quanta to $\mu \mathrm{mol}$ quanta; $\phi_{\max }$ is the maximum photosynthetic quantum yield at low irradiance in mol C (mol quanta) $)^{-1}$; and $\bar{a}_{p h(z, C h l)}^{*}$ is the weighted average of the specific absorption coefficient of phytoplankton, in $\mathrm{m}^{2}(\mathrm{mg} \mathrm{Chl})^{-1}$, where the weighting factor is the shape of the spectral distribution of in situ PAR (GilesGuzmán and Álvarez-Borrego 2000): donde $P_{m_{(z)}}^{*}$ es la razón fotosintética máxima en el óptimo de luz, normalizada por unidad de Chl, y se expresa en $\mathrm{mg} \mathrm{C} \mathrm{mg} \mathrm{Chl}{ }^{-1} \mathrm{~h}^{-1} ; \alpha_{P A R_{(z)}}^{*}$ es la pendiente inicial de la relación fotosíntesis-irradiancia (curva P-E), en mg C mg Chl ${ }^{-1}$ $\mathrm{h}^{-1}\left(\mu \mathrm{mol} \text { cuanta } \mathrm{m}^{-2} \mathrm{~s}^{-1}\right)^{-1}$; y PAR es la radiación fotosintéticamente activa en $\mu \mathrm{mol}$ cuanta $\mathrm{m}^{-2} \mathrm{~s}^{-1}$. La integración de la ecuación 1 con la profundidad es $\mathrm{PF}_{\mathrm{PS}}$. Para aguas caso I, se utilizó el modelo modificado con la expresión de GilesGuzmán y Álvarez-Borrego (2000) para el coeficiente específico de absorción del fitoplancton $\left(a_{p h(z, C h l)}^{*}\right)$. Esta modificación corrige la pendiente inicial de la relación fotosíntesisirradiancia por la forma de la distribución espectral de la PAR escalar in situ y por el efecto de paquete. Se utiliza $43.2 \phi_{\max } \bar{a}_{p h_{(z, C h l)}}^{*}$ en lugar de la pendiente inicial $\alpha_{P A R_{(z)}}^{*}$ (ec. 2). El factor 43.2 convierte los mol C a mg C, segundos a horas y mol cuanta a $\mu$ mol cuanta; $\phi_{\max }$ es el rendimiento cuántico máximo de la fotosíntesis a baja irradiancia y se expresa en mol C (mol cuanta) ${ }^{-1}$; y $\bar{a}_{p h(z, C h l)}^{*}$ es el promedio ponderado del coeficiente específico de absorción de luz del fitoplancton, en $\mathrm{m}^{2}(\mathrm{mg} \mathrm{Chl})^{-1}$, donde el factor de ponderación es la forma de la distribución espectral de PAR in situ (Giles-Guzmán y Álvarez-Borrego 2000):

$$
P P_{(z)}=\left[P_{m_{(z)}^{*}}^{*} C h l_{z} \bar{a}_{p h_{(z, c h l)}}^{*} \phi_{\max } P A R_{z}\right] \times\left[\left(0.02315 P_{m_{(z)}}^{*}\right)^{2}+\left(P A R_{z} \bar{a}_{p h_{(z, c h l)}}^{*} \phi_{\max }\right)^{2}\right]^{-0.5}
$$

Integration of equation 2 with depth provides $\mathrm{PP}_{\mathrm{GGAB}}$. Equations 1 and 2 show that, to calculate PP, vertical profiles of $\mathrm{Chl}_{(z)}$ and $\mathrm{PAR}_{(z)}$ are needed, not only the surface values (Hidalgo-González and Álvarez-Borrego 2004). The $\mathrm{Chl}_{(z)}$ vertical profiles were generated from $\mathrm{Chl}_{\mathrm{sat}}$ and the Gaussian model proposed by Platt et al. (1991), using the parameters reported by Hidalgo-González and Álvarez-Borrego (2001) for the NGC (their winter region IV and summer region 2). Monthly Aqua-MODIS composites for PAR incident on the sea surface $\left(\mathrm{PAR}_{0}\right)$ were used. This $\mathrm{PAR}_{0}$ is the integral for the whole day (daylight hours), also called diurnal insolation $Q$, and it is expressed as Einstein $\mathrm{m}^{-2}$ day $^{-1}$ (one Einstein is one mole photons, it is Avogadro's number of photons = $6.022 \times 10^{23}$ quanta). These values were transformed to $\mu \mathrm{mol}$ quanta $\mathrm{m}^{-2}$ day ${ }^{-1}$. PAR for noon is $\mathrm{PAR}_{m}=Q \pi / 2 N$, where $N$ is the daylight in seconds. PAR incident on the surface for each hour is $\mathrm{PAR}_{(t)}=\mathrm{PAR}_{m} \sin (\pi t / N)$, where $t$ is time in seconds from sunrise (Kirk 1994). PAR $_{(z)}$ profiles for case I waters were generated following Giles-Guzmán and ÁlvarezBorrego (2000), and for case II waters they were generated following Cervantes-Duarte et al. (2000). Valdez-Holguín
La integración de la ecuación 2 con la profundidad es $\mathrm{PF}_{\mathrm{GGAB}}$. Las ecuaciones 1 y 2 muestran que para calcular $\mathrm{PF}$, se necesitan perfiles verticales de $\mathrm{Chl}_{(z)}$ y $\operatorname{PAR}_{(z)}$, no sólo los valores superficiales (Hidalgo-González y Álvarez-Borrego 2004). Los perfiles verticales de $\mathrm{Chl}_{(z)}$ se obtuvieron a partir de los valores de $\mathrm{Chl}_{\text {sat }}$ y el modelo gaussiano propuesto por Platt et al. (1991), y los parámetros de ajuste reportados por Hidalgo-González y Álvarez-Borrego (2001) para el norte del golfo (su región IV de invierno y región 2 de verano). Se utilizaron las composiciones mensuales de PAR superficial $\left(\mathrm{PAR}_{0}\right)$ del sensor Aqua-MODIS. Esta $\mathrm{PAR}_{0}$ es la integral para todo el día (horas luz), o sea la insolación diurna $\mathrm{Q}$, y se expresa como Einstein $\mathrm{m}^{-2}$ día $^{-1}$ (un Einstein equivale a un mol de fotones, y es el número de Avogadro fotones = $6.022 \times 10^{23}$ cuanta). Estos valores se transformaron a $\mu \mathrm{mol}$ cuanta $\mathrm{m}^{-2}$ día $^{-1}$. PAR para mediodía es $\mathrm{PAR}_{m}=Q \pi / 2 N$, donde $N$ es el día-luz en segundos. El valor de PAR incidente en la superficie para cada hora es $\operatorname{PAR}_{(t)}=\operatorname{PAR}_{m} \operatorname{sen}(\pi \mathrm{t} / N)$, donde $t$ es el tiempo en segundos a partir del amanecer (Kirk 1994). Los perfiles de $\operatorname{PAR}_{(z)}$ para aguas caso I se generaron de acuerdo con Giles-Guzmán y Álvarez-Borrego 
et al.'s (1999) values for the photosynthetic parameters $\left(P_{m_{(z)}}^{*}, \alpha_{P A R_{(z)}}^{*}\right.$, and $\left.\phi_{\max }\right)$ were used. PP was calculated for each morning hour and multiplied by two to obtain PP for the whole day (symmetry of PAR and constancy of $\mathrm{Chl}_{(z)}$ were assumed for the day).

\section{Statistical analysis}

The distributions of the three variables (SST, $\mathrm{Chl}_{\mathrm{sat}}$, and PP) were not normal. Thus, non-parametric tests were run to search for spatial and temporal differences. The year was divided into winter and summer, following HidalgoGonzález and Álvarez-Borrego (2004), and a Mann-Whitney $\mathrm{U}$ test for two independent variables was performed to search for differences between seasons. To search for interannual differences, the winter averages for all years were compared by a Kruskal-Wallis test for multiple independent variables, and the same was done for the summer averages. An $a$ posteriori test was run to establish which winters and which summers were significantly different from the others. To search for spatial differences, a Kruskal-Wallis test for multiple independent variables was run separately with winter and with summer averages to compare quadrants. Also, an $a$ posteriori test was run to establish which quadrants were significantly different from the others.

A linear regression was run with $\mathrm{Ch}_{\text {sat }}$ data from each winter month as the dependent variable and the years as the independent variable, to search for a long-term significant negative tendency, separately for data from each sensor. The same was done for $\mathrm{PP}_{\mathrm{OSU}}$. A linear regression was performed between SeaWiFS and Aqua-Modis $\mathrm{Chl}_{\text {sat }}$ data from overlapping years (July 2002 to December 2010) in order to analyze the between-sensors consistency and explore the possibility of using data from them as a single time series. A linear regression was run between $\mathrm{PP}_{\mathrm{OSU}}$ and $\mathrm{PP}_{\mathrm{PS}}$ to test for a significant difference between the slope and the slope for the $45^{\circ}$ line (1.0). The same was done for $\mathrm{PP}_{\mathrm{OSU}}$ and $\mathrm{PP}_{\mathrm{GGAB}}$.

\section{RESULTS}

The SST values for the NGC presented a very clear annual oscillation $\left(15-31{ }^{\circ} \mathrm{C}\right)$. The time series for the four quadrants showed very similar SST values. SST minima occurred in February and March, and maxima in August and September (fig. 2a). The differences between the summer and winter SST values were significant (Mann-Whitney U test: $n$ $=436, z=-17.72, P<0.001)$. The highest winter mean SST was $19.98 \pm 0.75{ }^{\circ} \mathrm{C}$ (in this and all following cases the number after \pm is the standard error, $\mathrm{s} / \mathrm{n}^{0.5}$ ) in the SW quadrant in 2002-2003; the differences with the winter mean SST values for the other quadrants were smaller than the standard error. The winter of 2010-2011 had the lowest mean SST, with $18.4 \pm 0.86^{\circ} \mathrm{C}$ in the SE quadrant. On the other hand,
(2000), y los de aguas caso II se generaron de acuerdo a Cervantes-Duarte et al. (2000). Se utilizaron los valores de los parámetros fotosintéticos $\left(P_{m_{(z)}}^{*}, \alpha_{P A R_{(z)}}^{*} \mathrm{y} \phi_{\max }\right)$ de Valdez-Holguín et al. (1999). Se calculó la PF para cada hora de la mañana, y la suma se multiplicó por dos para obtener la PF de todo el día (se supuso simetría de PAR y constancia de $\mathrm{Chl}_{(z)}$ en el día).

\section{Análisis estadístico}

Las distribuciones de las tres variables (TSM, Chl $\mathrm{sat}_{\mathrm{s}} \mathrm{PF}$ ) no fueron normales, por lo que se hicieron pruebas no paramétricas para investigar diferencias espaciales y temporales. El año se dividió en invierno y verano, de acuerdo con Hidalgo-González y Álvarez-Borrego (2004). Para explorar diferencias entre estaciones, se realizó una prueba $U$ de Mann-Whitney para dos variables independientes. Para explorar diferencias interanuales, se compararon los promedios de invierno de todos los años mediante la prueba de Kruskal-Wallis para variables múltiples independientes, y se hizo lo mismo para promedios de verano. Además, se realizó una prueba a posteriori para establecer cuáles inviernos y cuáles veranos presentaban diferencias significativas con los otros. Para explorar variaciones espaciales se hicieron comparaciones entre cuadrantes mediante la prueba de Kruskal-Wallis para variables múltiples independientes con los promedios de invierno y con los de verano por separado. Además, se realizó una prueba a posteriori para establecer cuáles de los cuadrantes presentan diferencias significativas con los otros.

Para establecer si hubo una tendencia significativa negativa de periodo largo de $\mathrm{Chl}_{\text {sat }}$, se realizó un análisis de regresión lineal con los datos de $\mathrm{Chl}_{\text {sat }}$ de cada mes de los inviernos como variable dependiente y los años como variable independiente, por separado para cada uno de los sensores. Se hizo lo mismo para $\mathrm{PF}_{\mathrm{OSU}}$. Se realizó un análisis de regresión lineal entre los datos de $\mathrm{Ch}_{\text {sat }}$ de los años que se traslapan de los sensores SeaWiFS y MODIS Aqua (julio de 2002 a diciembre de 2010), con la finalidad de observar si había inter-consistencia entre sensores y poder tomar los datos como una sola serie de tiempo. Se realizó una regresión lineal entre $\mathrm{PF}_{\mathrm{OSu}} \mathrm{y} \mathrm{PF}_{\mathrm{PS}}$ para probar si había una diferencia significativa entre la pendiente y la de la línea de $45^{\circ}(1.0)$. Lo mismo se hizo para $\mathrm{PF}_{\mathrm{OSU}}$ y $\mathrm{PF}_{\mathrm{GGAB}}$.

\section{RESUltados}

La TSM en el NGC presentó una oscilación anual muy marcada $\left(15-31^{\circ} \mathrm{C}\right)$. Las series de tiempo de los cuatro cuadrantes mostraron valores de TSM muy similares. Los valores mínimos de TSM se presentaron en febrero y marzo, y los máximos en agosto y septiembre (fig. 2a). Las diferencias entre las TSMs de invierno y de verano fueron significativas (prueba $U$ de Mann-Whitney: $n=436, z=-17.72$, 

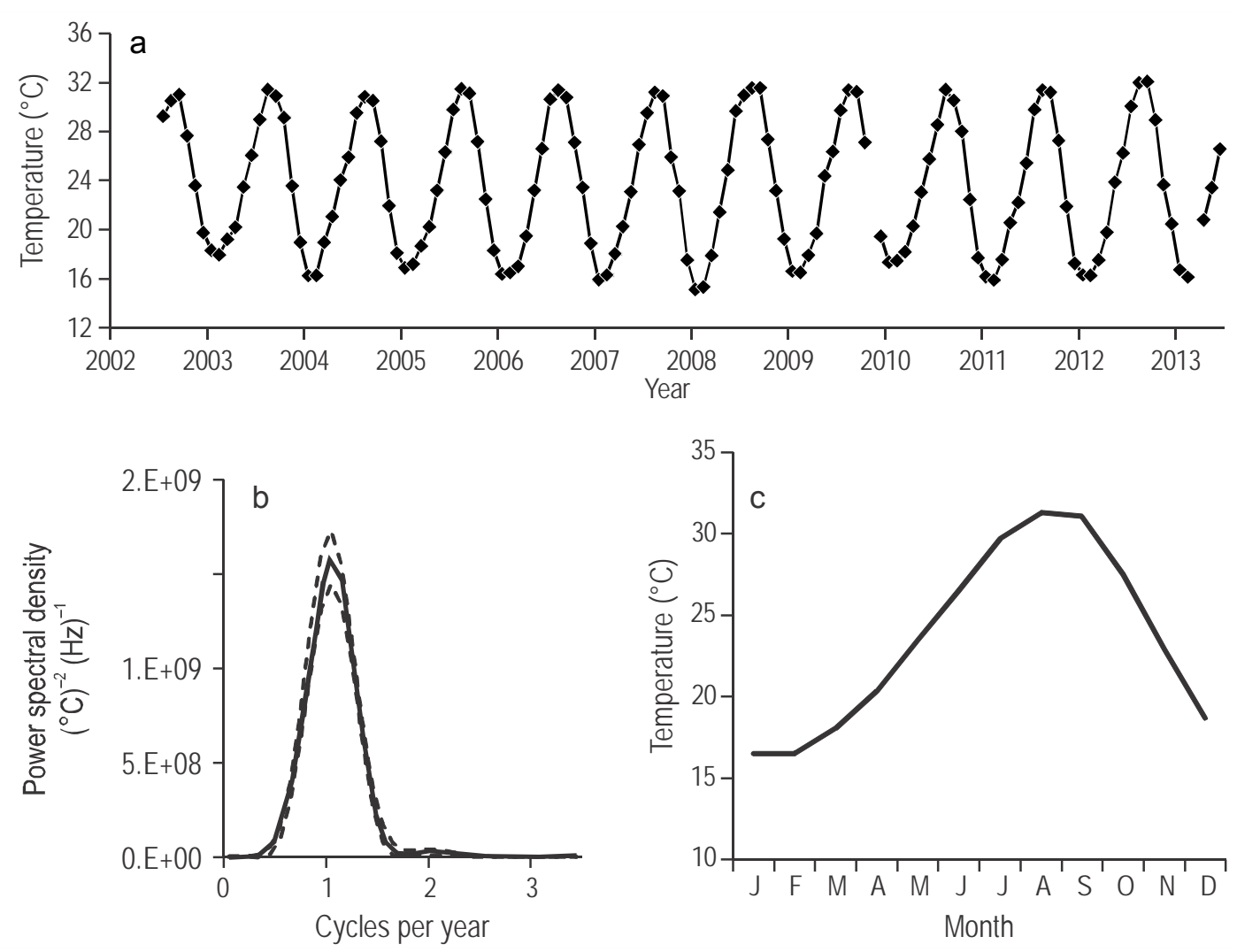

Figure 2. Sea surface temperature $\left({ }^{\circ} \mathrm{C}\right)$. (a) Time series of data from the NW quadrant: the standard error is smaller than the symbols and the marks on the horizontal axis indicate the beginning of the year. (b) Spectral density of data from the NW quadrant: the continuous line is the average and the broken line marks the limits at the 95\% confidence level. (c) Average year for the NW quadrant.

Figura 2. Temperatura superficial del mar $\left({ }^{\circ} \mathrm{C}\right)$. (a) Serie de tiempo de los datos del cuadrante NW: el error estándar es menor que el tamaño de los símbolos y las marcas en el eje horizontal indican el inicio del año. (b) Densidad espectral de los datos del cuadrante NW: la línea continua es el promedio y la línea discontinua marca los límites al 95\% de nivel de confianza. (c) Año promedio del cuadrante NW.

the lowest summer mean SST was $28.87 \pm 0.78^{\circ} \mathrm{C}$ in the $\mathrm{NE}$ quadrant in 2002 , whereas the summer of 2012 was the warmest, with $30.75 \pm 0.76^{\circ} \mathrm{C}$ in the NW quadrant. However, SST did not present a significant interannual variation. Winter SST values showed no significant differences between years (Kruskal-Wallis test: $n=260, H=13.41$, $P=0.20)$, and neither did the summer SST values (Kruskal-Wallis test: $n=176, H=14.09, P=0.16$ ). The spectral analysis showed that the seasonal cycle explained most of the SST variability in all four quadrants. This signal was the only significant one (fig. 2b). The four spectra are very similar, and show a very small, but not significant maximum in the semiannual cycle.

In relation to the approximation to the climatology, the mean SST for February was the lowest, with $16.51 \pm 0.23{ }^{\circ} \mathrm{C}$ in the NW quadrant, and the mean for August was the highest, with $31.31 \pm 0.12^{\circ} \mathrm{C}$ also in the NW quadrant (fig. 2c). There were no significant differences between quadrants in both seasons (Kruskal-Wallis test: $n=260, H=0.56$, $P=0.90$ for winter; and $n=176, H=5.74, P=0.12$ for summer).
$P<0.001)$. El promedio de TSM más alto para invierno fue el de 2002-2003, con $19.98 \pm 0.75^{\circ} \mathrm{C}$ (en éste y en todos los casos siguientes, el número después de \pm es el error estándar, $\mathrm{S} / \mathrm{n}^{0.5}$ ) para el cuadrante $\mathrm{SW}$; las diferencias con los promedios de los otros cuadrantes fueron menores que el error estándar. El invierno de 2010-2011 fue el que presentó el promedio más bajo, con $18.4 \pm 0.86^{\circ} \mathrm{C}$ en el cuadrante SE. Por otro lado, el promedio más bajo de TSM para verano se presentó en 2002 , con $28.87 \pm 0.78^{\circ} \mathrm{C}$ en el cuadrante $\mathrm{NE}, \mathrm{y}$ el verano de 2012 fue el más cálido, con $30.75 \pm 0.76{ }^{\circ} \mathrm{C}$ en el cuadrante NW. Sin embargo, la TSM no presentó una variación interanual significativa. Los valores de TSM de invierno no presentaron diferencias significativas entre años (prueba de Kruskal-Wallis: $n=260, H=13.41, P=0.20)$, ni tampoco los de verano (prueba de Kruskal-Wallis: $n=176, H=14.09$, $P=0.16$ ). El análisis espectral mostró que el ciclo estacional es el que explica la mayor parte de la variabilidad de la TSM en los cuatro cuadrantes. Esta señal fue la única significativa (fig. 2b). Los cuatro espectros son muy similares. Los espectros muestran un máximo muy pequeño en la frecuencia semianual pero no fue estadísticamente significativo. 
The time series from the three sensors show a clear difference between winter and summer $\mathrm{Chl}_{\text {sat }}$ values in the NGC (figs. 3, 4). Chl $1_{\text {sat }}$ showed components of seasonal and between-year variation during the 1978-1986 period (CZCS). The CZCS composites, unlike the imagery from the other sensors, often lacked data for the NW quadrant (figs. 3, 4). In general, the NW quadrant had the highest mean $\mathrm{Chl}_{\text {sat }}$ values and the SE quadrant the lowest. The CZCS time series for the four quadrants showed a very clear seasonal variation $\left(0.4\right.$ to $\left.5 \mathrm{mg} \mathrm{m}^{-3}\right)$, with minimum values in summer and maximum in winter. There were significant differences between the summer and winter $\mathrm{Chl}_{\text {sat }}$ values
Con relación a la aproximación a la climatología, la TSM promedio de los febreros fue el más bajo, con $16.51 \pm 0.23{ }^{\circ} \mathrm{C}$ en el cuadrante NW. El promedio de agosto fue el más alto, con $31.31 \pm 0.12{ }^{\circ} \mathrm{C}$ también en el cuadrante NW (fig. 2c). No hubo diferencias significativas entre cuadrantes en ambas épocas del año (prueba de Kruskal-Wallis: $n=260, H=0.56$, $P=0.90$ para invierno; y $n=176, H=5.74, P=0.12$ para verano).

Las series de tiempo de los tres sensores mostraron una clara diferencia entre los valores de $\mathrm{Ch}_{\text {sat }}$ de invierno y los de verano para el NGC (figs. 3, 4). Chl sat mostró componentes de variación estacional y entre años en el periodo 1978-1986

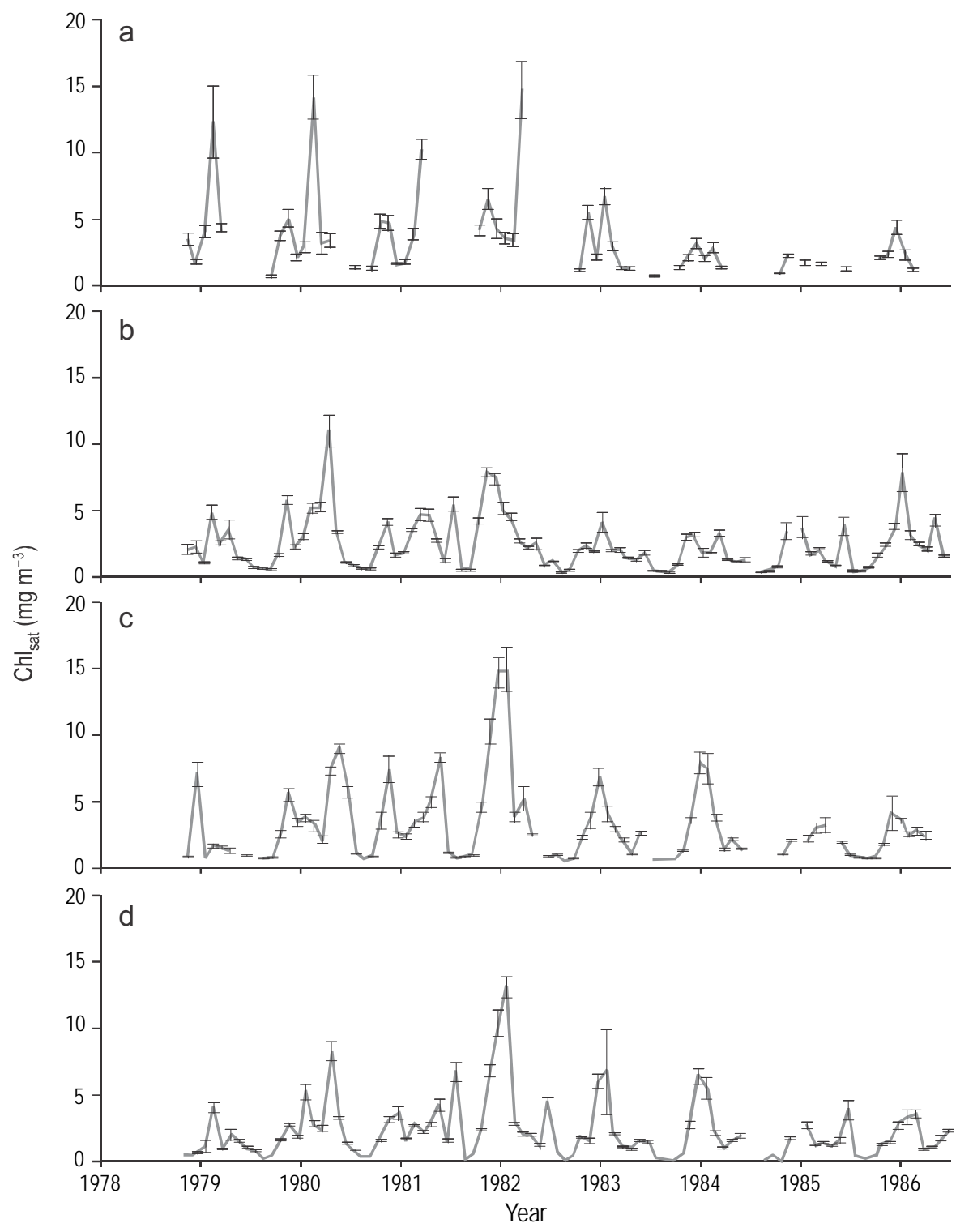

Figure 3. Time series of CZCS Chl sat data for the four quadrants, for the period 1978-1986: (a) NW, (b) NE, (c) SW, and (d) SE. Vertical bars show the standard error. Marks on the horizontal axis indicate the beginning of the year.

Figura 3. Series de tiempo de $\mathrm{Chl}_{\text {sat }}$ del sensor CZCS para los cuatro cuadrantes, para el periodo 1978-1986: (a) NW, (b) NE, (c) SW y (d) SE. Las barras verticales muestran el error estándar. Las marcas en el eje horizontal indican el inicio del año. 


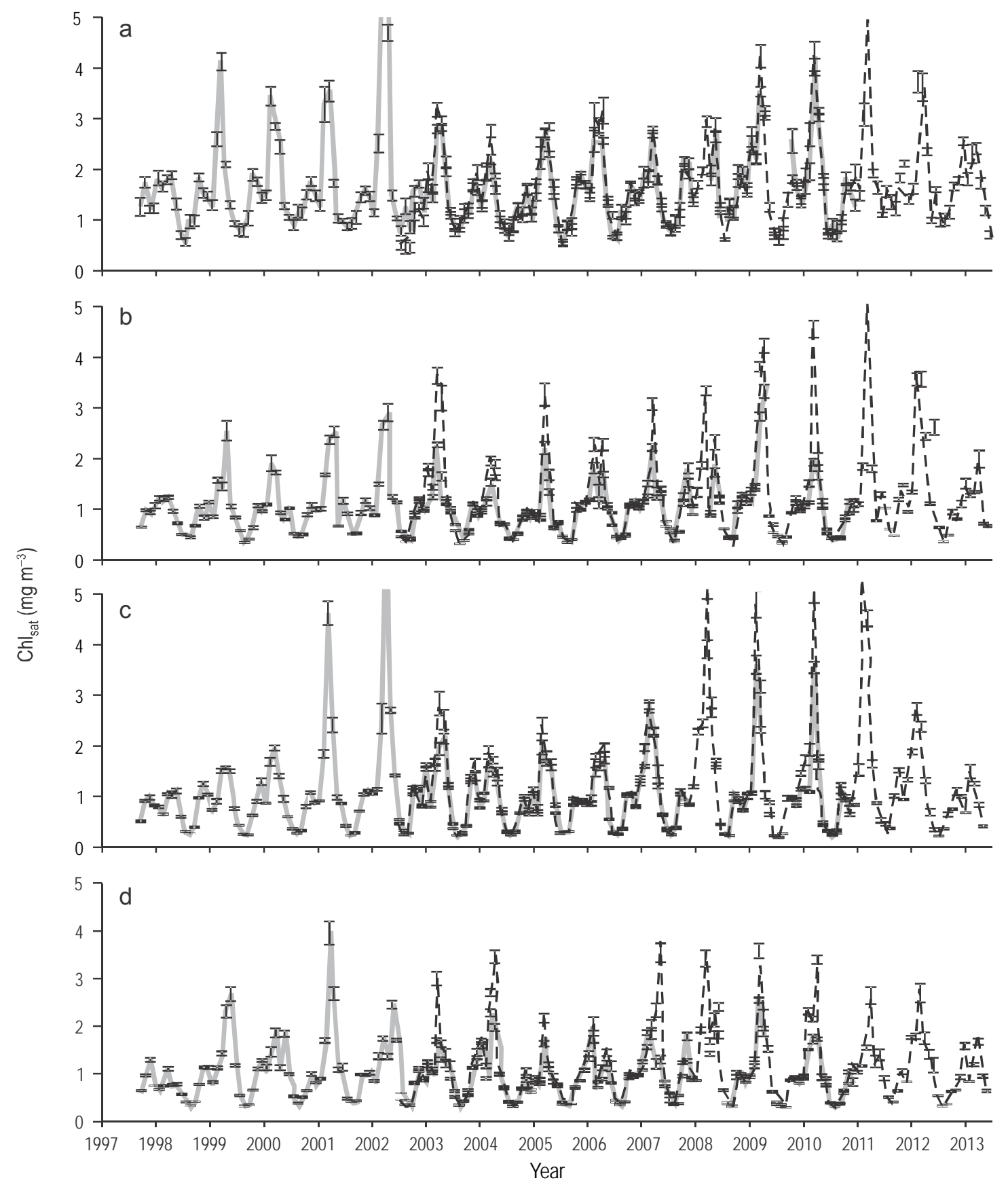

Figure 4. Time series of $\mathrm{Chl}_{\text {sat }}$ data from SeaWiFS (continuous line) and Aqua-MODIS (broken line) for the four quadrants, for the 1997-2013 period: (a) NW, (b) NE, (c) SW, and (d) SE. Vertical bars show the standard error. Marks on the horizontal axis indicate the beginning of the year.

Figura 4. Series de tiempo de $\mathrm{Chl}_{\text {sat }}$ de los sensores SeaWiFS (línea continua) y Aqua MODIS (línea discontinua) para los cuatro cuadrantes, para el periodo 1997-2013: (a) NW, (b) NE, (c) SW y (d) SE. Las barras verticales muestran el error estándar. Las marcas en el eje horizontal indican el inicio del año.

(Mann-Whitney U test: $n=256, \mathrm{z}=9.83, P<0.001$ ). Besides the seasonal and interannual variations, $\mathrm{Chl}_{\text {sat }}$ had a semiannual variation that can be seen as a secondary maximum in the time series for the four quadrants. This other maximum was much smaller than the one for winter and was
(CZCS). A diferencia de las imágenes de los otros sensores, las del CZCS tuvieron muchos vacíos en el cuadrante NW (fig. 3, 4). En general, el cuadrante NW presentó los valores promedio de $\mathrm{Chl}_{\mathrm{sat}}$ más altos y el SE los más bajos. Las series de tiempo del CZCS de los cuatro cuadrantes presentaron una 
observed more clearly in the NW quadrant than in the others. It occurred in different times of different years, between the end of summer and end of autumn, and sometimes instead of a peak it was a shoulder (figs. 3, 4).

The internannual differences between the CZCS $\mathrm{Chl}_{\text {sat }}$ values for the winter months were significant (Kruskal-Wallis test: $n=167, H=31.66, P<0.001$ ). The winter of 1981-1982 had the highest mean $\mathrm{Chl}_{\text {sat }}$, with $8.46 \pm 2.95 \mathrm{mg} \mathrm{m}^{-3}$ in the NE quadrant, although differences between quadrants were smaller than the standard error. The winter of 1984-1985 had the lowest, with $1.7 \pm 0.04 \mathrm{mg} \mathrm{m}^{-3}$ in the NW quadrant, again without significant differences between quadrants. On the other hand, the internannual differences between the CZCS Chl $l_{\text {sat }}$ values for the summer months were not significant (Kruskal-Wallis test: $n=89$, $H=12.88, P>0.05$ ).

The SeaWiFS and Aqua-MODIS $\mathrm{Chl}_{\text {sat }}$ time series behaved very similar to the CZCS time series, with semiannual, annual, and interannual variations; however, when both sensors overlapped, the Aqua-MODIS winter $\mathrm{Chl}_{\text {sat }}$ values were higher than those from SeaWiFS, while the summer $\mathrm{Chl}_{\text {sat }}$ values from both sensors were similar (fig. 4). Linear regression analysis was performed for SeaWiFS vs AquaMODIS Chl sat with data from the period when both sensors operated at the same time, in order to decide on whether it was appropriate to use both data sets as a single time series. The regression had a slope of $0.73 \pm 0.014$ and $r^{2}=0.88$ using all data. Separating the data into case I waters $\left(\mathrm{Chl}_{\text {sat }}<1.5 \mathrm{mg} \mathrm{m}^{-3}\right)$ and case II waters $\left(\mathrm{Chl}_{\text {sat }}>1.5 \mathrm{mg} \mathrm{m}^{-3}\right)$, the regression for case I waters had a slope of $0.86 \pm 0.017$ and $r^{2}=0.9$, while that for case II waters had a slope of $0.21 \pm 0.66$ and $r^{2}=0.11$. In general, in both cases, the AquaMODIS $\mathrm{Ch}_{\text {sat }}$ data were higher than the SeaWiFS data, but they were very similar in the case of small $\mathrm{Chl}_{\text {sat }}$ values, whereas in the case of large $\mathrm{Chl}_{\text {sat }}$ values, the Aqua-MODIS data were higher and more scattered than the SeaWiFS data. Thus, both sets of data must be treated separately.

Comparing the SeaWiFS $\mathrm{Ch}_{\text {sat }}$ values for the winter months, the interannual variation was significant (Kruskal-Wallis test: $n=300, H=23.28, P=0.02$ ). The lowest mean SeaWiFS Chl sat was $0.76 \pm 0.06 \mathrm{mg} \mathrm{m}^{-3}$ in the SE quadrant in 1997-1998. The interannual variation of the SeaWiFS Chl $1_{\text {sat }}$ values for the summer months was not significant (Kruskal-Wallis test: $n=205, H=13.35, P=0.42$ ). Aqua-MODIS $\mathrm{Chl}_{\text {sat }}$ values for the winter months did not show a significant interannual variation (Kruskal-Wallis test: $n=264, H=12.80, P=0.23)$, with the same result for the interannual variation of the summer months $(n=176$, $H=9.26, P=0.50$ ).

The NW quadrant $\mathrm{Chl}_{\text {sat }}$ values were higher than those of the other three quadrants throughout the time series from the three sensors (for CZCS data, Kruskal-Wallis test: $n=89$, $H=14.5, P=0.0023$; and similar for data from the other sensors). The lowest $\mathrm{Chl}_{\text {sat }}$ values were very similar in the variación estacional muy marcada (de 0.4 a $5 \mathrm{mg} \mathrm{m}^{-3}$ ), con mínimos en verano y máximos en invierno. Las diferencias de $\mathrm{Chl}_{\text {sat }}$ entre invierno y verano fueron significativas (prueba U de Mann-Whitney: $n=256, z=9.83, P<0.001$ ). Además de las variaciones interanual y estacional, la $\mathrm{Chl}_{\text {sat }}$ tuvo un componente semianual, que se visualiza como un máximo secundario (a la manera del cálculo diferencial) en las series de tiempo de los cuatro cuadrantes. Este otro máximo fue de mucha menor magnitud que el de invierno y se mostró más claramente en el cuadrante NW que en los otros. Se presentó en tiempos diferentes para años diferentes, entre el final de verano y el final de otoño, y algunas veces en lugar de un pico era un hombro (figs. 3, 4).

Las diferencias interanuales entre los meses de invierno fueron significativas (prueba de Kruskal-Wallis: $n=167$, $H=31.66, P<0.001)$. La $\mathrm{Chl}_{\mathrm{sat}}$ promedio más alta para invierno se presentó en 1981-1982, con $8.46 \pm 2.95 \mathrm{mg} \mathrm{m}^{-3}$ en el cuadrante NE, aunque las diferencias entre cuadrantes fueron más pequeñas que el error estándar. El valor más bajo se presentó en 1984-1985, con $1.7 \pm 0.04 \mathrm{mg} \mathrm{m}^{-3}$ en el cuadrante NW, de nuevo sin diferencias significativas entre cuadrantes. Por otro lado, las diferencias interanuales de $\mathrm{Chl}_{\text {sat }}$ del CZCS no fueron significativas para verano (prueba de Kruskal-Wallis: $n=89, H=12.88, P>0.05$ ).

Las series de tiempo de $\mathrm{Chl}_{\text {sat }}$ del SeaWiFS y del AquaMODIS se comportaron de una manera muy similar a la del CZCS, con variaciones semianuales, anuales e interanuales; sin embargo, en el traslapo de ambos sensores, la $\mathrm{Chl}_{\text {sat }}$ de invierno derivada del Aqua-MODIS fue mayor que la del SeaWiFS, mientras que los valores de $\mathrm{Chl}_{\text {sat }}$ de verano de ambos sensores fueron similares (fig. 4). Se realizó un análisis de regresión lineal de SeaWIFS $\mathrm{Chl}_{\text {sat }}$ vs AquaMODIS Chl $\mathrm{sat}_{\mathrm{t}}$ con los datos del periodo en el que ambos sensores operaron al mismo tiempo, con el propósito de decidir si era apropiado usar ambos conjuntos de datos como una sola serie de tiempo. La regresión tuvo una pendiente de $0.73 \pm 0.014$ y $r^{2}=0.88$ utilizando todos los datos. Separando los datos en aguas caso I $\left(\mathrm{Chl}_{\mathrm{sat}}<1.5 \mathrm{mg} \mathrm{m}^{-3}\right)$ y caso II $\left(\mathrm{Chl}_{\mathrm{sat}}>1.5 \mathrm{mg} \mathrm{m}^{-3}\right)$, la regresión para aguas caso I tuvo una pendiente igual a $0.86 \pm 0.017$ y $r^{2}=0.9$, mientras que la de aguas caso II tuvo una pendiente de $0.21 \pm 0.66 \mathrm{y}^{2}=0.11$. En general, en ambos casos, los datos de $\mathrm{Chl}_{\text {sat }}$ de AquaMODIS fueron mayores que los de SeaWIFS, pero fueron muy similares en el caso de los valores bajos de $\mathrm{Chl}_{\text {sat }}$, mientras que en el caso de los valores altos de $\mathrm{Ch}_{\text {sat }}$, los datos del Aqua-MODIS fueron mayores y más dispersos que los del SeaWiFS. Por lo tanto, ambos conjuntos de datos tienen que ser tratados separadamente.

Comparando los valores de $\mathrm{Chl}_{\text {sat }}$ del SeaWIFS de los meses de invierno, la variación interanual fue significativa (prueba de Kruskal-Wallis: $n=300, H=23.28, P=0.02$ ). La $\mathrm{Chl}_{\text {sat }}$ del SeaWIFS presentó el promedio más bajo de invierno en 1997-1998, con $0.76 \pm 0.06 \mathrm{mg} \mathrm{m}^{-3}$ en el cuadrante SE. Comparando los valores de $\mathrm{Chl}_{\text {sat }}$ del SeaWIFS 
other three quadrants. The difference between the NW quadrant and the other three is made clearer by the summer data. During the CZCS period, the lowest summer value for the NW quadrant was $>1 \mathrm{mg} \mathrm{m}^{-3}$, whereas it was $\sim 0.4 \mathrm{mg} \mathrm{m}^{-3}$ for the other quadrants. During the SeaWiFS and Aqua-MODIS periods, minimum summer $\mathrm{Ch}_{\text {sat }}$ values were $>0.9 \mathrm{mg} \mathrm{m}^{-3}$ for the NW quadrant, and they were $0.3-0.4 \mathrm{mg} \mathrm{m}^{-3}$ in the other quadrants. This $\mathrm{Chl}_{\mathrm{sat}}$ spatial variation was not clear for winter. Winter $\mathrm{Ch}_{\text {sat }}$ data from CZCS and Aqua-MODIS showed no significant differences between quadrants (Kruskal-Wallis test: $n=167, H=2.46, P=0.46$; and $n=264, H=6.4, P=0.93$, respectively), while those from SeaWiFS showed significant differences, with values for the NW quadrant higher than those for the other quadrants (Kruskal-Wallis test: $n=300, H=54.03, P<0.001$ ).

The approximation to the $\mathrm{Chl}_{\text {sat }}$ climatology in the NGC shows a very clear seasonal variation for the three sensors (fig. 5a-b). The highest mean $\mathrm{Ch}_{\text {sat }}$ values are those of March and April in the case of SeaWIFS and Aqua-MODIS, and those of February, November, and December in the case of CZCS. In all three cases, there are two maxima, but they were clearer in the CZCS climatology. Winter CZCS values were more than double those of the other two sensors. The lowest mean $\mathrm{Chl}_{\text {sat }}$ values were observed in July, August, and September, and they were very similar for the three sensors. As a comparison, the climatology for Guaymas Basin also shows that the winter CZCS values are more than double those of the other sensors (fig. 5c).

Linear regression analysis to explore the possibility of a long-period $\mathrm{Chl}_{\text {sat }}$ trend, run separately for each sensor and for each quadrant, resulted in low correlation coefficients and non-significant slopes (for the NW quadrant and for data from the three sensors: $n=31, F=2.73, P=0.11 ; n=96, F=$ $0.35, P=0.55$; and $n=66, F=1.10, P=0.30$, respectively for CZCS, SeaWIFS, and Aqua-MODIS). The spectral analysis showed a strong annual signal (seasonal cycle) that causes most of the $\mathrm{Ch}_{\text {sat }}$ variability in the NGC. It also showed a $\mathrm{Chl}_{\text {sat }}$ semiannual signal (two cycles per year), but smaller than the annual and only significant for data from AquaMODIS, at the $95 \%$ confidence level (fig. $6 a-b$ ).

The NGC PP showed a spatial and temporal variability very similar to that of $\mathrm{Chl}_{\mathrm{sat}}$, with a clear difference between winter and summer values (2002-2013 period) (fig. 7a-b). Besides the seasonal variation, PP had a semiannual component, which was corroborated by the spectral analysis (fig. 7c). The interannual variation was not significant (Kruskal-Wallis test: $n=264, H=11.67, P=0.30$ for winter; and $n=176, H=9.27, P=0.50$ for summer). In general, the NW quadrant had the highest average PP, mainly in summer. In the first approximation to the PP climatology, March and April were the most productive, with $\sim 3.3 \pm 0.2 \mathrm{~g} \mathrm{C} \mathrm{m}^{-2}$ day $^{-1}$. On the other hand, the period July-September was the least productive, with $\sim 1.1 \mathrm{~g} \mathrm{C} \mathrm{m}^{-2}$ day $^{-1}$ in the NW quadrant and $0.5-0.6 \mathrm{~g} \mathrm{C} \mathrm{m}^{-2} \mathrm{day}^{-1}$ in the other quadrants (fig. $7 \mathrm{~d}$ ). para los meses de verano, la variación interanual no fue significativa (prueba de Kruskal-Wallis: $n=205, H=13.35$, $P=0.42$ ). Los valores de $\mathrm{Ch}_{\text {sat }}$ del Aqua-MODIS para los meses de invierno no mostraron una variación interanual significativa (prueba de Kruskal-Wallis: $n=264, H=12.80$, $P=0.23$ ), y se obtuvo el mismo resultado para la variación interanual de los meses de verano $(n=176, H=9.26$, $P=0.50$ ).

Los valores de $\mathrm{Ch}_{\text {sat }}$ del cuadrante NW fueron mayores que los de los otros tres cuadrantes a lo largo de las series de tiempo de los tres sensores (para los datos del CZCS, prueba de Kruskal-Wallis: $n=89, H=14.5, P=0.002$, y similar para los datos de los otros sensores). Los valores de $\mathrm{Chl}_{\text {sat }}$ más bajos fueron muy similares entre los otros tres cuadrantes. Esta diferencia entre el cuadrante NW y los otros tres es más clara en los datos de verano. Durante el periodo del CZCS el valor mínimo de verano fue $>1 \mathrm{mg} \mathrm{m}^{-3}$ para el cuadrante NW, mientras que en los otros cuadrantes fue de $\sim 0.4 \mathrm{mg} \mathrm{m}^{-3}$. Durante los periodos del SeaWiFS y AquaMODIS, los valores mínimos de $\mathrm{Chl}_{\text {sat }}$ de verano fueron $>0.9 \mathrm{mg} \mathrm{m}^{-3}$ en el cuadrante NW y $0.3-0.4 \mathrm{mg} \mathrm{m}^{-3}$ en los otros cuadrantes. Esta variación espacial de la $\mathrm{Ch}_{\text {sat }}$ no fue clara para invierno. Los valores de $\mathrm{Chl}_{\mathrm{sat}}$ de invierno de los sensores CZCS y Aqua-MODIS no presentaron diferencias significativas entre cuadrantes (prueba de Kruskal-Wallis: $n=167, H=2.46, P=0.46$; y $n=264, H=6.4, P=0.93$, respectivamente), mientras que los del SeaWiFS tuvieron diferencias significativas, con valores mayores para el cuadrante NW que para los demás cuadrantes (prueba de Kruskal-Wallis: $n=300, H=54.03, P<0.001$ ).

La aproximación a la climatología de $\mathrm{Chl}_{\text {sat }}$ del NGC muestra una variación estacional muy clara para los tres sensores (fig. 5a-b). Los valores promedio de $\mathrm{Chl}_{\text {sat }}$ más elevados son los de marzo y abril en el caso del SeaWIFS y del Aqua-MODIS, y los de febrero, noviembre y diciembre en el caso del CZCS. En los tres casos se muestran dos máximos, pero fueron mucho más marcados en la climatología del CZCS. Los valores de invierno del CZCS fueron más del doble que los de los otros sensores. Los valores promedio más bajos de $\mathrm{Chl}_{\mathrm{sat}}$ se registraron en julio, agosto y septiembre y fueron muy similares para los tres sensores. Como comparación, se muestra que también los valores de invierno del CZCS de la cuenca de Guaymas fueron más del doble que los de los otros sensores (fig. 5c).

El análisis de regresión lineal para explorar la posibilidad de una tendencia de $\mathrm{Ch}_{\text {sat }}$ de periodo largo, por separado para cada sensor y para cada cuadrante, resultó en coeficientes de correlación bajos y pendientes no significativas (para el cuadrante NW y los datos de los tres sensores: $n=31, F=2.73$, $P=0.109 ; n=96, F=0.35, P=0.554 ;$ y $n=66, F=1.10$, $P=0.297$, respectivamente para CZCS, SeaWIFS y AquaMODIS). El análisis espectral mostró una señal anual fuerte (ciclo estacional) que causa la mayor parte de la variabilidad de $\mathrm{Chl}_{\text {sat }}$ en el NGC. También mostró una señal semianual de 

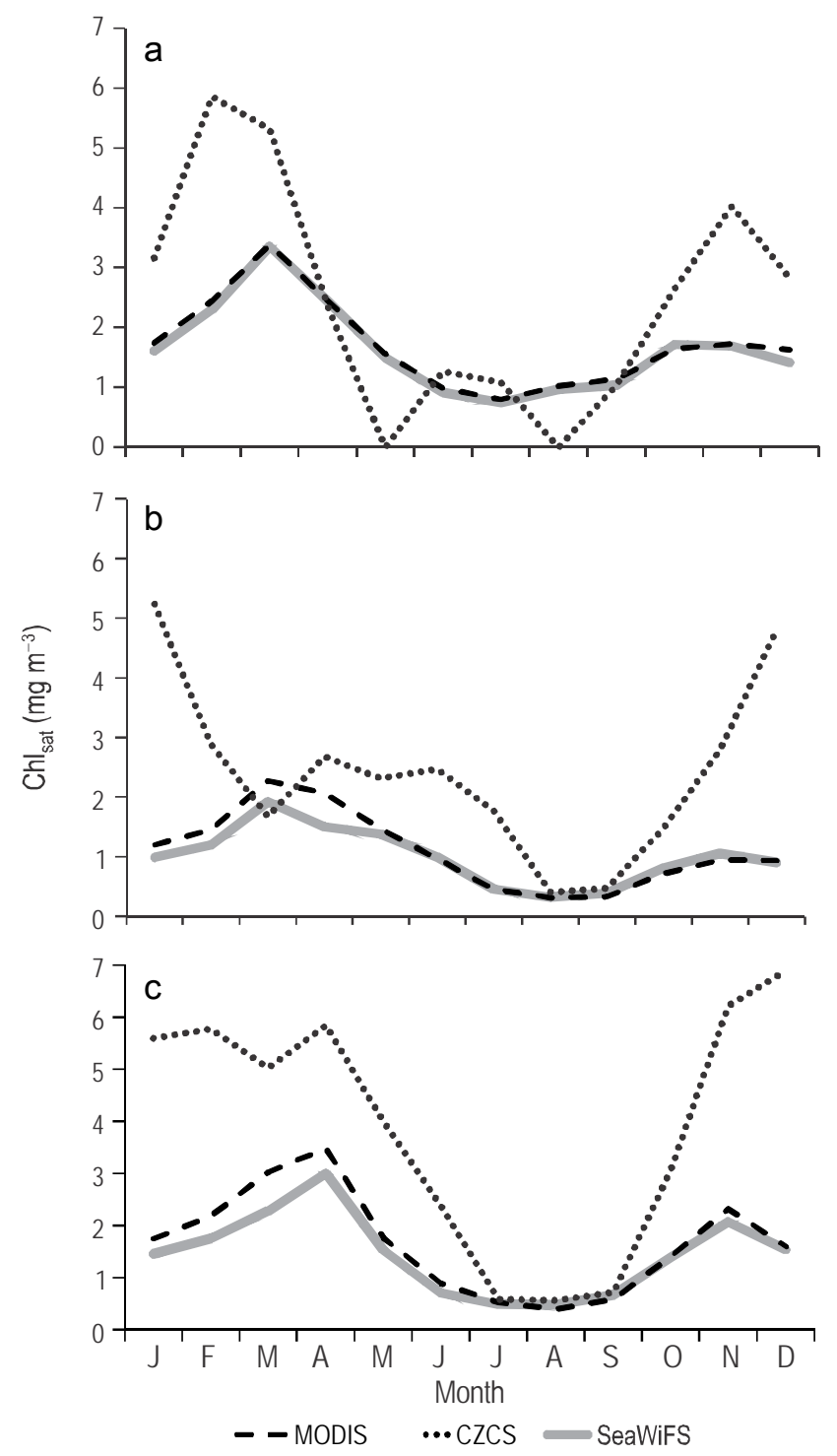

Figure 5. Approximation to the $\mathrm{Chl}_{\text {sat }}$ climatology of the (a) NW and (b) SE quadrants in the northern Gulf of California and (c) Guaymas Basin quadrant. The broken line represents AquaMODIS data, the dotted line represents CZCS data, and the continuous line represents SeaWiFS data.

Figura 5. Aproximación a la climatología de $\mathrm{Chl}_{\text {sat }}$ de los cuadrantes (a) NW y (b) SE en el norte del golfo de California y (c) del cuadrante de la cuenca de Guaymas. La línea discontinua representa los datos del sensor Aqua-MODIS, la línea punteada los del sensor CZCS y la línea continua los del sensor SeaWiFS.

Of the $40 \mathrm{Chl}_{\text {sat }}$ and PAR data chosen at random to calculate PP using Platt et al.'s (1991) model, 28 were for case I waters and 12 were for case II waters. For case I waters, the slope of the $\mathrm{PP}_{\mathrm{OSU}} v s \mathrm{PP}_{\mathrm{GGAB}}$ relationship was $2.817 \pm 0.008$, thus $\mathrm{PP}_{\mathrm{OSU}}$ was up to $\sim 3$ times $\mathrm{PP}_{\mathrm{GGAB}}$. Linear regression analysis was statistically significant $(n=28, F=90.53$, $P<0.001)$, with a relatively high correlation coefficient $(r=0.79)$ (fig. 8a). For case II waters, the slope of the
$\mathrm{Ch}_{\mathrm{sat}}$ (dos ciclos por año) pero más pequeña que la anual y sólo significativa para los datos del Aqua-MODIS, al 95\% de nivel de confianza (fig. 6a-b).

La PF del NGC presentó una variabilidad temporal y espacial muy similar a la de $\mathrm{Chl}_{\text {sat }}$, con una diferencia clara entre los valores de invierno y los de verano (periodo 2002-2013) (fig. 7a-b). Además de la variación estacional, la PF tuvo una componente semianual, lo cual se corroboró con el análisis espectral (fig. 7c). La variación interanual no fue significativa (prueba de Kruskal-Wallis: $n=264, H=11.67$, $P=0.30$ para invierno, y $n=176, H=9.27, P=0.50$ para verano). En general, el cuadrante NW presentó el PF promedio más alto, sobre todo en verano. En la primera aproximación a la climatología de PF, marzo y abril fueron los más productivos, con $\sim 3.3 \pm 0.2 \mathrm{~g} \mathrm{C} \mathrm{m}^{-2} \mathrm{día}^{-1}$. Por otro lado, el periodo de julio a septiembre fue el menos productivo, con $\sim 1.1 \mathrm{~g} \mathrm{C} \mathrm{m}^{-2}$ día $^{-1}$ en el cuadrante NW y $0.5-0.6 \mathrm{~g} \mathrm{C} \mathrm{m}^{-2}$ día $^{-1}$ en los otros cuadrantes (fig. 7d).

De los 40 datos de $\mathrm{Chl}_{\text {sat }}$ y PAR que se eligieron al azar para calcular PF a partir del modelo de Platt et al. (1991), 28 fueron para aguas caso I y 12 para aguas caso II. Para aguas caso I, la pendiente de la relación $\mathrm{PF}_{\mathrm{OSU}} v s \mathrm{PF}_{\mathrm{GGAB}}$ fue

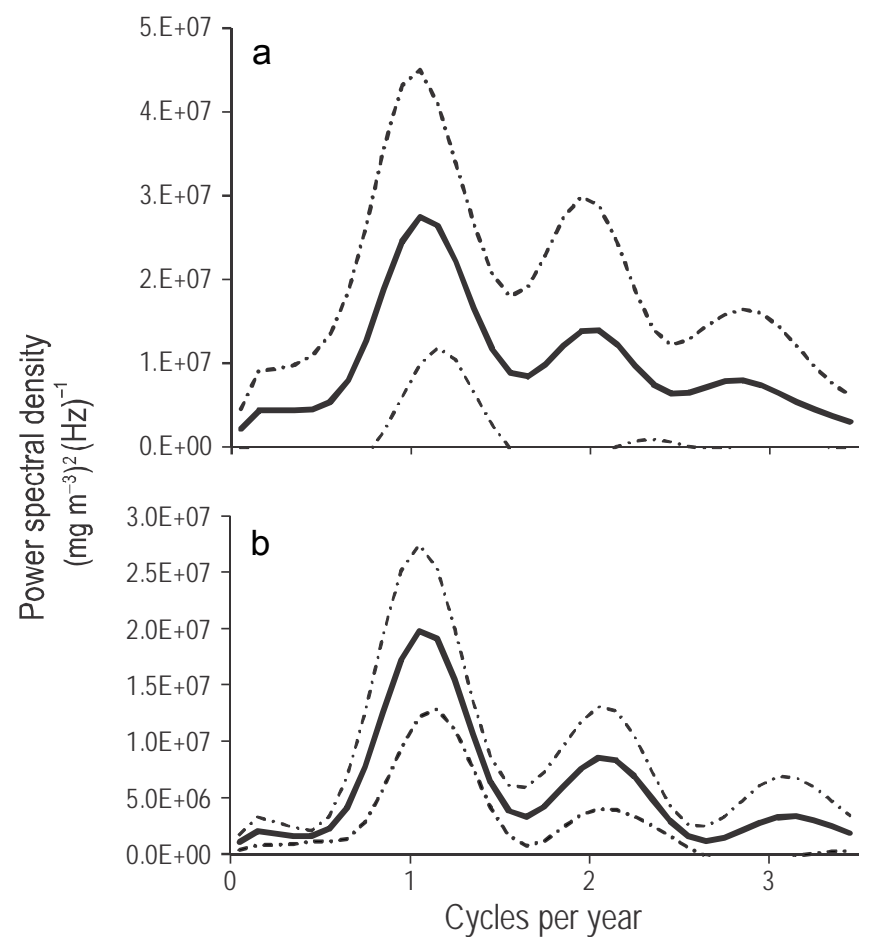

Figure 6. Spectral density of $\mathrm{Chl}_{\text {sat }}$ for the NW quadrant: (a) SeaWiFS data and (b) Aqua-MODIS data. The continuous line is the average and the broken line marks the limits at the $95 \%$ confidence level.

Figura 6. Densidad espectral de $\mathrm{Chl}_{\text {sat }}$ para el cuadrante NW: (a) datos del sensor SeaWiFS y (b) datos del sensor Aqua-MODIS. La línea continua es el promedio y la línea discontinua marca los límites al 95\% de nivel de confianza. 

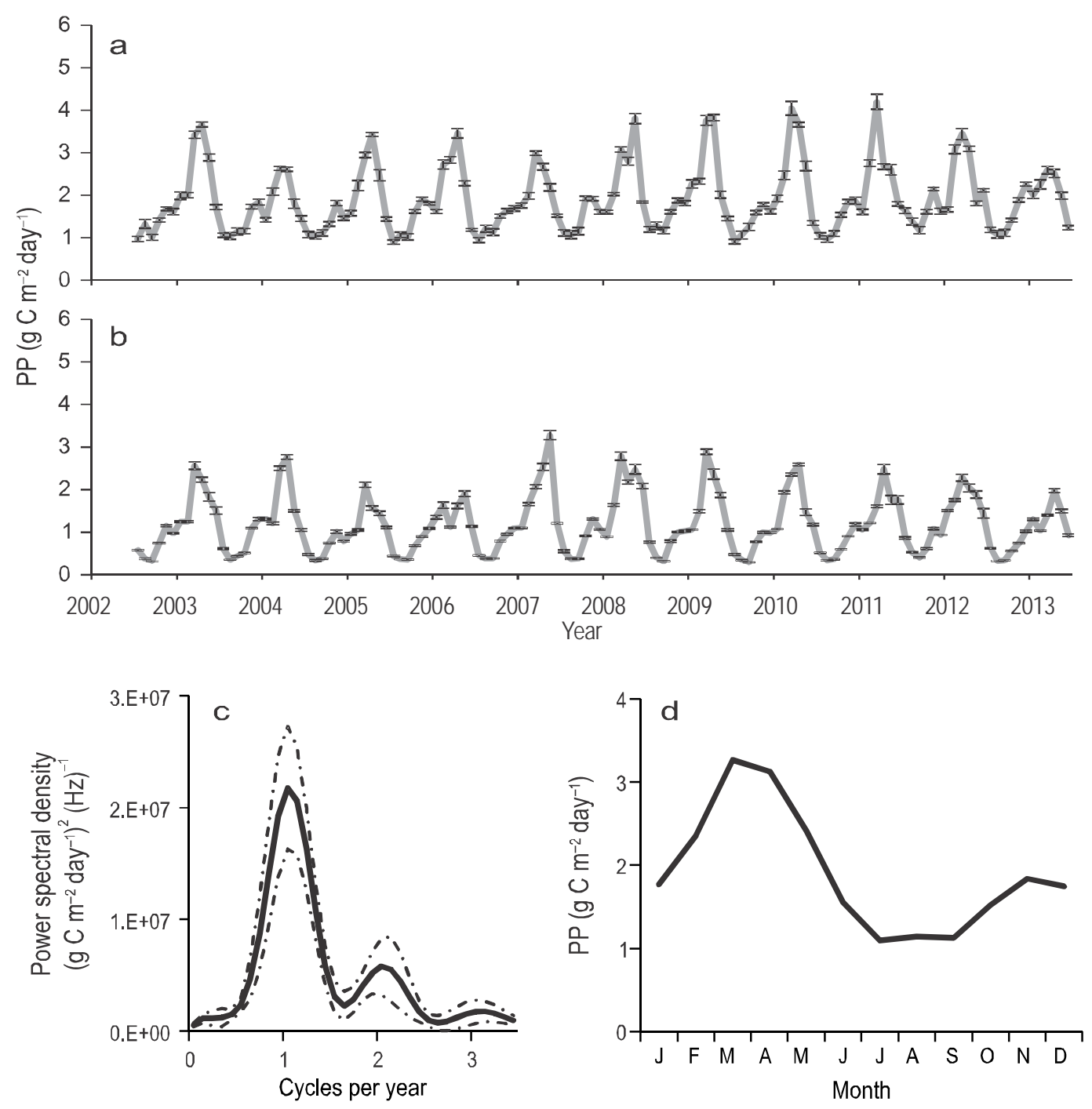

Figure 7. Primary production. Time series for the (a) NW quadrant and (b) SE quadrant: vertical bars show the standard error and the marks on the horizontal axis indicate the beginning of the year. (c) Spectral density of data from the NW quadrant: the continuous line is the average and the broken line marks the limits at the $95 \%$ confidence level. (d) Average year for the NW quadrant.

Figura 7. Producción primaria. (a) Series de tiempo del cuadrante NW y (b) del cuadrante SE: las barras verticales muestran el error estándar y las marcas en el eje horizontal indican el inicio del año. (c) Densidad espectral del cuadrante NW: la línea continua es el promedio y la línea discontinua marca los límites de confianza al 95\%. (d) año promedio del cuadrante NW.

$\mathrm{PP}_{\mathrm{OSU}}$ vs $\mathrm{PP}_{\mathrm{PS}}$ relationship was $0.446 \pm 1.233$; thus, in general, $\mathrm{PP}_{\mathrm{OSU}}$ was smaller than $\mathrm{PP}_{\mathrm{PS}}\left(\mathrm{PP}_{\mathrm{OSU}}\right.$ was greater than $\mathrm{PP}_{\mathrm{PS}}$ only in two cases). Linear regression analysis, however, was not statistically significant $(n=12, F=1.33, P=0.274)$ $(r=0.42)$ (fig. 8b).

\section{DiSCUSSION}

The record of the Colorado River flow across the Mexico-US border shows that before 1935, when the filling of Lake Mead (Hoover Dam) began, the freshwater that was discharged into the Upper Gulf had a seasonal modulation with peak discharges in June. After construction of the Glen Canyon Dam, input of Colorado River water to the Upper
$2.817 \pm 0.008$, es decir $\mathrm{PF}_{\mathrm{OSU}}$ fue hasta $\sim 3$ veces $\mathrm{PF}_{\mathrm{GGAB}}$. El análisis de regresión lineal fue estadísticamente significativo ( $n=28, F=90.53, P<0.001)$, con un coeficiente de correlación relativamente elevado $(r=0.79)$ (fig. 8a). Para aguas caso II, la pendiente de la relación $\mathrm{PF}_{\mathrm{OSU}}$ Vs $\mathrm{PF}_{\mathrm{PS}}$ fue $0.446 \pm 1.233$; es decir, en general $\mathrm{PF}_{\mathrm{OSU}}$ fue menor que $\mathrm{PF}_{\mathrm{PS}}$ $\left(\mathrm{PF}_{\mathrm{OSU}}\right.$ fue mayor que $\mathrm{PF}_{\mathrm{PS}}$ en sólo dos casos). Sin embargo, el análisis de regresión no fue estadísticamente significativo $(n=12, F=1.33, P=0.274)(r=0.56)$ (fig. $8 b)$.

\section{DISCUSIÓN}

El registro del flujo del río Colorado, en el cruce de la frontera entre México y Estados Unidos, muestra que antes 

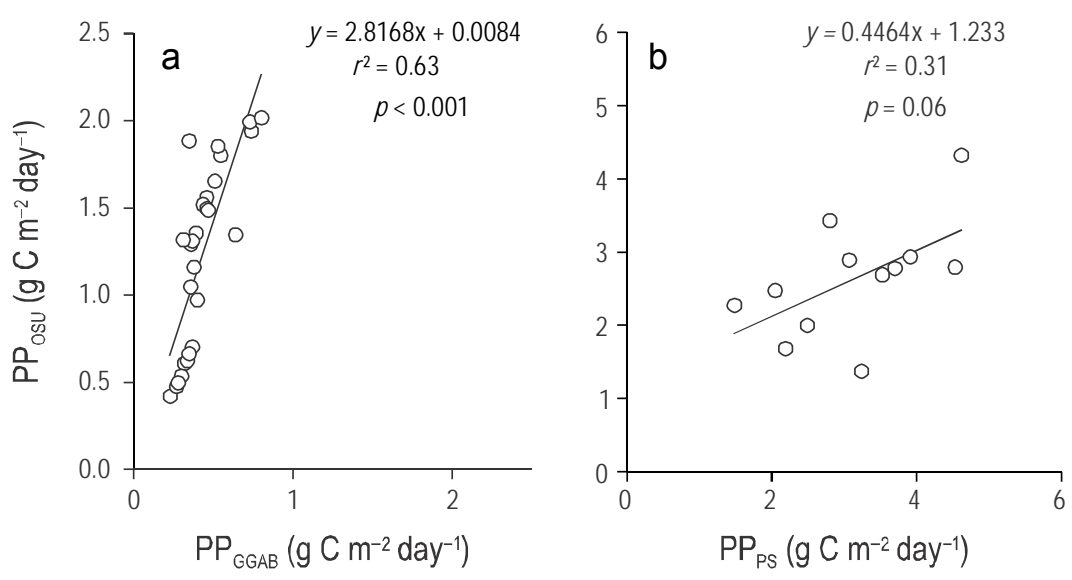

Figure 8. Linear regression between primary productivity $(\mathrm{PP})$ data from Oregon State University's Ocean Productivity website $\left(\mathrm{PP}_{\mathrm{OSU}}\right)$ and PP estimated with Platt et al.'s (1991) model for (a) case I waters and (b) case II waters.

Figura 8. Regresión lineal entre los datos de productividad primaria (PP) del sitio web Ocean Productivity $\left(\mathrm{PP}_{\mathrm{OSU}}\right)$ y $\mathrm{PP}$ del modelo de Platt et al. (1991) para (a) aguas caso I y (b) aguas caso II.

Gulf completely stopped (in 1961). During 1979-1987, water releases became necessary because of abnormal high precipitation and snowmelts in the upper river basin. Water releases also occurred in 1993 and 1997-2002 (Álvarez-Borrego 2002). Before the dams, there was a large interannual variation of river flow into the Upper Gulf, with a maximum of $>32 \times 10^{9} \mathrm{~m}^{3} \mathrm{yr}^{-1}$ and a minimum of $<10 \times 10^{9} \mathrm{~m}^{3} \mathrm{yr}^{-1}$ in the first 30 years of the 20th century. The largest water release in the period 1979-1987 was $>15 \times 10^{9} \mathrm{~m}^{3} \mathrm{yr}^{-1}$, similar to that of the river flowing freely.

When the Colorado River flowed freely, its influence was restricted to a few tens of kilometers to the southwest of the mouth, and was not felt throughout the whole NGC. Lavín and Sánchez (1999) reported that when the river flowed into the sea in 1993, the river plume with significantly mixed water only extended $\sim 70 \mathrm{~km}$ southwestwards from the mouth, close to the peninsula. Rodríguez et al. (2001) used ${ }^{18} \mathrm{O}$ in shells of a bivalve endemic to the Colorado River estuary (Mulinia coloradoensis Dall 1894) to reconstruct the river influence area before the construction of the dams and concluded that it extended to a maximum of $\sim 80 \mathrm{~km}$ to the southwest of the mouth.

Nieto-García (1998) compared nutrient concentrations in the Upper Gulf in the spring of 1993 with those of spring 1996, when there was no water input from the Colorado River, and found that $\mathrm{NO}_{3}$ and $\mathrm{PO}_{4}$ concentrations were lower in 1993 than in 1996, and only silicate concentrations were higher in 1993. When comparing our $\mathrm{Chl}_{\mathrm{sat}}$ data for wet years with those of dry years, the differences were not significant. Thus, processes like mixing caused by tidal currents and coastal upwelling are causing the NGC to be productive, and nutrients from the Colorado River are not necessary to maintain its high PP.

Galindo-Bect et al. (2000) reported that higher shrimp catches landed in San Felipe were associated with river water de 1935, cuando empezó a funcionar la presa Hoover, el agua dulce que se descargaba en el Alto Golfo tenía una modulación estacional con máximos en junio. Después de la construcción de la presa Glen Canyon, el aporte de agua del río Colorado al Alto Golfo cesó por completo (en 1961). En el periodo 1979-1987 fue necesario dejar correr agua del río hasta el mar debido a las precipitaciones y deshielos anómalos que ocurrieron en la cuenca alta. Lo mismo sucedió en 1993 y en 1997-2002 (Álvarez-Borrego 2003). Antes de existir las presas, había una gran variación interanual del aporte de agua del río al Alto Golfo, con un máximo de $>32 \times 10^{9} \mathrm{~m}^{3}$ año ${ }^{-1}$ y un mínimo de $<10 \times 10^{9} \mathrm{~m}^{3}$ año $^{-1}$, en los primeros 30 años del siglo XX. El aporte más grande del periodo 1979-1987 fue $>15 \times 10^{9} \mathrm{~m}^{3}$ año ${ }^{-1}$, similar al flujo libre del río.

Cuando el río Colorado fluía libremente, su influencia se restringía a unas decenas de kilómetros al suroeste de su desembocadura y no en todo el NGC. Lavín y Sánchez (1999) reportaron que la lengüeta de agua significativamente mezclada del río Colorado sólo se extendió $\sim 70 \mathrm{~km}$ al suroeste de la boca, cerca de la península, cuando fluyó hasta el mar en 1993. Rodríguez et al. (2001) utilizaron ${ }^{18} \mathrm{O}$ en conchas de un bivalvo endémico del estuario del río Colorado (Mulinia coloradoensis Dall 1894) para reconstruir la zona de influencia del río antes de la construcción de las presas y concluyeron que se extendía hasta un máximo de $\sim 80 \mathrm{~km}$ al suroeste de la desembocadura.

Nieto-García (1998) comparó la concentración de nutrientes en el Alto Golfo de primavera de 1993 con las de primavera de 1996, cuando no hubo aporte de agua del río Colorado. Las concentraciones de $\mathrm{NO}_{3}$ y $\mathrm{PO}_{4}$ fueron menores en 1993 que en 1996 y sólo los silicatos fueron más altos en 1993. Comparando nuestros datos de $\mathrm{Chl}_{\text {sat }}$ para años húmedos con los de años secos, las diferencias no fueron significativas. Por lo tanto, procesos como la mezcla ocasionada 
discharges in the period 1976-1996, and a log-log regression with a one-year lag for the catches explained $45 \%$ of the variance. Aragón-Noriega and Calderón-Aguilera (2000) indicated that an important factor explaining the shrimp population increase is that expanded habitat (wetlands for shrimp larvae, postlarvae, and juveniles) is available when the Colorado River flow increases, because freshwater floods areas that are dry in those years when river discharge is null or too low. Furthermore, a commercial fishery for the Gulf corvina, Cynoscion othonopterus, a fish endemic to the Upper Gulf of California, existed from 1917 to 1940 but collapsed in the early 1960s. This collapse was attributed to fishing practices and the reduction in flow of the Colorado River into the Gulf of California, which supposedly reduced available nursery habitat for juveniles (Román-Rodríguez 2000). Nevertheless, the corvina fishery reappeared during the 1990s and continues to date (Aragón-Noriega 2014), in spite of the general lack of freshwater input to the Upper Gulf.

In general, the NGC has been considered a highly productive region. High winter $\mathrm{Ch}_{\text {sat }}$ values ranging from 1 to $>5 \mathrm{mg} \mathrm{m}^{-3}$ have been reported (Santamaría-del-Ángel et al. 1994a). Strictly, it is not appropriate to compare $\mathrm{Ch}_{\mathrm{sat}}$ and satellite-derived PP data with those from oceanographic cruises, because the two data sets have totally different time and space scales: satellite data are averages for $9 \times 9 \mathrm{~km}^{2}$ areas and for one month, whereas data from oceanographic cruises are instantaneous point measurements. Nevertheless, the comparison is interesting. Winter $\mathrm{Chl}$ data generated during oceanographic cruises also ranged from 2 to $>5 \mathrm{mg} \mathrm{m}^{-3}$, with very few values of up to $20 \mathrm{mg} \mathrm{m}^{-3}$ (Gendrop-Funes et al. 1978, Álvarez-Borrego and Gaxiola-Castro 1988, Gaxiola-Castro et al. 1995, Valdez-Holguín et al. 1995), similar in general to the $\mathrm{Chl}_{\text {sat }}$ data presented in this study. Time series of Chl data generated from in situ sampling at sites close to the coast off San Felipe (Baja California) and Santa Clara (Sonora) show values $<1.0 \mathrm{mg} \mathrm{m}^{-3}$ for September, values between $\sim 1.5$ and $>5 \mathrm{mg} \mathrm{m}^{-3}$ for February, and values $>20 \mathrm{mg} \mathrm{m}^{-3}$ for May (Álvarez-Borrego 2002), again similar to the $\mathrm{Chl}_{\text {sat }}$ values presented here. Álvarez-Borrego and Lara-Lara (1991) reported only six ${ }^{14} \mathrm{C}$ PP data points for the $\mathrm{NGC}$, ranging from 0.6 to $2.3 \mathrm{~g} \mathrm{C} \mathrm{m}^{-2} \mathrm{day}^{-1}$, with the highest values for June and lowest values for November. ÁlvarezBorrego and Lara-Lara's (1991) low values agree with our summer values, but their high winter values are only about $70 \%$ of the satellite-derived PP values. Although point and instantaneous ${ }^{14} \mathrm{C}$ PP data are extremely scarce, the comparison indicates that satellite-derived values might be overestimating PP.

The main source of interannual changes in the ocean climate of the Gulf of California is the El Niño influence (Baumgartner and Christensen 1985), and this also applies to

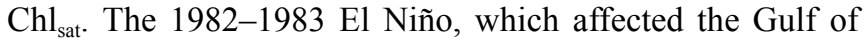
California throughout 1984, and the 1997-1998 El Niño occurred during our study period (Santamaría-del-Ángel por corrientes de marea y las surgencias costeras son los causantes de que el NGC sea un ecosistema productivo, y los nutrientes del río Colorado no son necesarios para mantener su alta PF.

Galindo-Bect et al. (2000) reportaron que las capturas más altas de camarón que arribaron a San Felipe se asociaron con descargas de agua del río en el periodo 1976-1996, y que una regresión log-log con un año de desfase para las capturas explicaron $45 \%$ de la variancia. Aragón-Noriega y CalderónAguilera (2000) indicaron que un factor importante para explicar el aumento de las poblaciones de camarón es que el hábitat expandido (humedales para larvas, postlarvas y juveniles de camarón) está disponible cuando los flujos del río Colorado aumentan, porque el agua dulce inunda áreas que están secas en los años cuando las descargas del río son muy bajas o nulas. Por otro lado, la pesquería comercial de la corvina golfina, Cynoscion othonopterus, un pez endémico al alto golfo de California, que existió de 1917 a 1940, se colapsó en la década de los años sesenta. Este colapso se atribuyó a las prácticas de pesca y a la reducción del aporte de agua del río Colorado al golfo de California, lo cual supuestamente reducía el hábitat disponible para sus juveniles (Román-Rodríguez 2000). Sin embargo, la pesquería de la corvina reapareció en la década de los años noventa y continúa hasta el presente (Aragón-Noriega 2014), a pesar de que en general no se cuenta con el aporte de agua del río al Alto Golfo.

En general, el NGC ha sido considerado como una región altamente productiva. Se han reportado valores altos de $\mathrm{Ch}_{\text {sat }}$ de invierno, entre 1 y $>5 \mathrm{mg} \mathrm{m}^{-3}$ (Santamaría-del-Ángel et al. 1994a). Estrictamente, no es apropiado comparar datos de $\mathrm{Chl}_{\text {sat }}$ y de PF derivados de satélite con los de cruceros oceanográficos, porque las escalas temporal y espacial de los dos tipos de muestreo son muy diferentes: los datos de satélite son promedios mensuales y para áreas de $9 \times 9 \mathrm{~km}^{2}$, mientras que los de cruceros son instantáneos y puntuales. Sin embargo, la comparación es interesante. Los valores de invierno de $\mathrm{Chl}$ obtenidos de cruceros oceanográficos también oscilaron entre $2 \mathrm{y}>5 \mathrm{mg} \mathrm{m}^{-3}$, con muy pocos valores de hasta $20 \mathrm{mg} \mathrm{m}^{-3}$ (Gendrop-Funes et al. 1978, ÁlvarezBorrego y Gaxiola-Castro 1988, Gaxiola-Castro et al. 1995, Valdez-Holguín et al. 1995), similares en general a los datos de $\mathrm{Chl}_{\text {sat }}$ presentados en este estudio. Series de tiempo de datos de Chl generados con muestreos in situ para localidades cerca de la costa frente a San Felipe (Baja California) y Santa Clara (Sonora) muestran valores $<1.0 \mathrm{mg} \mathrm{m}^{-3}$ para septiembre, entre $\sim 1.5 \mathrm{y}>5 \mathrm{mg} \mathrm{m}^{-3}$ para febrero y hasta $>20 \mathrm{mg} \mathrm{m}^{-3}$ para mayo (Álvarez-Borrego 2002), de nuevo similares a los de Chlsat presentados aquí. Álvarez-Borrego y Lara-Lara (1991) reportaron sólamente seis valores puntuales de PF $\left({ }^{14} \mathrm{C}\right)$ para el NGC, en un rango de 0.6 a $2.3 \mathrm{~g} \mathrm{C} \mathrm{m}^{-2} \mathrm{dí}^{-1}$, con el valor más alto para junio y el más bajo para noviembre. Los valores bajos de Álvarez-Borrego y Lara-Lara (1991) concuerdan con nuestros valores de verano, pero sus valores altos de invierno son sólo cerca de 70\% de los valores de PF 
et al. 1994b, Hidalgo-González and Álvarez-Borrego 2004), both of the Eastern Pacific type. Santamaría-del-Ángel et al. (1994b) reported a decrease in $\mathrm{Ch}_{\text {sat }}$ values for the winters of 1982-1983 and 1983-1984 relative to the 1981-1982 values, but they reported that the impact was not the same throughout the gulf. In the NGC and the region of the big islands, $\mathrm{Chl}_{\text {sat }}$ differences between El Niño years and non-El Niño years were not significant, while differences were very clear for southern localities. Likewise, the effects of the 1997-1998 El Niño on the NGC were less evident than in the southern gulf (Hidalgo-González and Álvarez-Borrego 2004, Kahru et al. 2004). In this study, a significant decrease in $\mathrm{Chl}_{\text {sat }}$ for the winter of 1983-1984 with respect to that for 1981-1982 is reported, due to the effect of El Niño, in spite of the large Colorado River water input of 1984 . Also, this study reports a significant decrease in $\mathrm{Chl}_{\text {sat }}$ values for the winter of 1997-1998 with respect to those for 1999-2000, for the four quadrants, because of the 1997-1998 El Niño, in agreement with the values for the whole NGC reported by HidalgoGonzález and Álvarez-Borrego (2004), and Kahru et al. (2004), again in spite of the Colorado River water input. However, the NGC Chl sat values were not lower than $1.0 \mathrm{mg} \mathrm{m}^{-3}$ in the case of both 1982-1984 and 1997-1998. The decrease in $\mathrm{Chl}_{\text {sat }}$ in 1997-1998 was similar in the four quadrants of the NGC (fig. 4), contrary to what HerreraCervantes et al. (2010) reported. These latter authors concluded that the effect of the 1997-1998 El Niño was greater in the northwestern portion than in the rest of the NGC.

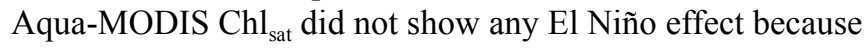
the events of the 2002-2013 period were of the Central Pacific type.

The semiannual component of variation is caused by the sequence of intense stratification during summer and mixing during autumn due to mesoscale processes, such as the change from cyclonic to anticyclonic circulation as described by Lavín et al. (1997). In early autumn, stratification weakens and because of the effect of mixing processes nutrients are transported to the euphotic zone, although not as efficiently as with coastal upwelling, generating a secondary $\mathrm{Chl}_{\text {sat }}$ maximum in October (figs. 3, 4).

The PP graphs parallel those of $\mathrm{Chl}_{\text {sat }}$ (figs. 4, 7). Even though the calculated PP fields depend on SST, PAR, and daylength, $\mathrm{Ch}_{\text {sat }}$ dominated the variability in PP, as was also reported by Kahru et al. (2004) and Álvarez-Molina et al. (2013) for the whole gulf. Hidalgo-González and ÁlvarezBorrego (2004) and Kahru et al. (2004) reported that the seasonal cycle is the one with most $\mathrm{Chl}_{\text {sat }}$ and PP variation in the NGC. Since several decades ago, it is well known that the $\mathrm{Chl}_{\mathrm{sat}}$ and PP seasonal cycle is strongly determined by upwelling events caused by northwesterly winds off the continental coast during winter and strong stratification during summer due to southeasterly winds (Álvarez-Borrego and Lara-Lara 1991).

The high $\mathrm{Ch}_{\text {sat }}$ values from CZCS were clearly higher than those from SeaWiFS and Aqua-MODIS, which could derivados de satélite. Aunque los datos de PF de 14C, instantáneos y puntuales,son extremadamente escasos, la comparación indica que los valores derivados de satélite podrían estar sobre-estimando PF.

La fuente principal de cambios interanuales del clima oceánico en el golfo de California es la influencia de El Niño (Baumgartner y Christensen 1985), y esto también se aplica a $\mathrm{Ch}_{\text {sat }}$. Durante nuestro periodo de estudio se presentaron El Niño 1982-1983, cuyo efecto en el golfo de California se extendió hasta 1984, y El Niño 1997-1998 (Santamaría-delÁngel et al. 1994b, Hidalgo-González y Álvarez-Borrego 2004), ambos del tipo de El Niño del Pacífico Oriental. Santamaría-del-Ángel et al. (1994b) reportaron un decremento de $\mathrm{Ch}_{\text {sat }}$ para los inviernos de 1982-1983 y 1983-1984, con respecto a los valores de 1981-1982. Sin embargo, estos últimos autores reportaron que el impacto no fue el mismo en todo el golfo. En las regiones de las Islas Grandes y NGC, las diferencias de $\mathrm{Ch}_{\text {sat }}$ no fueron significativas entre los años El Niño y los no El Niño, mientras que en las localidades sureñas las diferencias fueron muy claras. De manera similar, los efectos de El Niño 1997-1998 en el NGC fueron menos evidentes que en el sur del golfo (HidalgoGonzález y Álvarez-Borrego 2004, Kahru et al. 2004). En este estudio se reporta para el NGC un decremento significativo de $\mathrm{Chl}_{\text {sat }}$ para el invierno 1983-1984 con respecto del de 1981-1982, debido al efecto de El Niño, a pesar del gran aporte de agua del río Colorado en 1984. También se reporta en este estudio una disminución significativa de $\mathrm{Chl}_{\text {sat }}$ para el invierno de 1997-1998 con respecto a los de 1999-2000, por la influencia de El Niño 1997-1998, de acuerdo con los valores para todo lo ancho del NGC de Hidalgo-González y Álvarez-Borrego (2004) y Kahru et al. (2004), de nuevo a pesar del aporte de agua del río Colorado. Sin embargo, tanto en el caso de 1982-1984 como en el de 1997-1998, los valores de $\mathrm{Ch}_{\text {sat }}$ de invierno no fueron menores a $1.0 \mathrm{mg} \mathrm{m}^{-3} \mathrm{en} \mathrm{el}$ NGC. El decremento de $\mathrm{Chl}_{\text {sat }}$ en 1997-1998 fue similar en los cuatro cuadrantes del NGC (fig. 4), contrario a lo reportado por Herrera-Cervantes et al. (2010), quienes concluyeron que el efecto de El Niño 1997-1998 fue mayor en la porción noroccidental que en el resto del NGC. Los datos de Chlsat del Aqua-MODIS no mostraron el efecto de ningún evento El Niño porque los eventos del período 2002-2013 fueron del tipo del Pacífico Central.

La variación semianual se debe a la secuencia de condiciones de estratificación intensa en verano y de mezcla en otoño ocasionada por procesos de mesoescala, como la reversión de la circulación ciclónica a anticiclónica descrita por Lavín et al. (1997). Al inicio de otoño, la estratificación se debilita y por efecto de los procesos de mezcla hay transporte de nutrientes a la zona eufótica, aunque no es tan eficaz como el acarreo por surgencia costera, formándose un máximo secundario de $\mathrm{Chl}_{\text {sat }}$ en octubre (figs. 3, 4).

Las gráficas de PF son muy similares a las de $\mathrm{Chl}_{\text {sat }}$ (figs. 4, 7). Aunque el cálculo de PF depende de TSM, PAR y la longitud del día, la $\mathrm{Chl}_{\text {sat }}$ domina la variabilidad de $\mathrm{PF}$, 
lead us to conclude that there has been a decrease in phytoplankton biomass from the 1970s and 1980s through the 2000s, because of the deterioration of the NGC's pelagic ecosystem caused by the lack of Colorado River water and its nutrients. However, these $\mathrm{Chl}_{\text {sat }}$ differences could have been caused by differences in the optical design of the sensors and not by changes in the environmental conditions of the NGC. For example, Kahru et al. (2012) reported differences between the $\mathrm{Ch}_{\text {sat }}$ values deduced from four sensors (OCTS, SeaWiFS, Aqua-MODIS, and MERIS) for the California Current System. In this study, differences between sensors are proven with $\mathrm{Chl}_{\text {sat }}$ data from Guaymas Basin, which is a region with very high winter $\mathrm{Chl}_{\text {sat }}$ and PP values, and where there is no effect caused by the lack of nutrients from rivers. High Chl $\mathrm{sat}_{\text {at }}$ data from CZCS for the Guaymas Basin were also clearly much higher than those from the other two sensors, very similar to that observed for the NGC (fig. 5c). Thus, CZCS overestimates $\mathrm{Ch}_{\text {sat }}$ values higher than $0.5 \mathrm{mg} \mathrm{m}^{-3}$ by as much as $>5$ times (fig. 5 ).

The summer $\mathrm{Chl}_{\text {sat }}$ and PP differences between the NW and the other quadrants were caused by the greater concentrations of organic matter in the former, both as detritus and as color dissolved organic matter (CDOM). These optical components of seawater strongly attenuate light at short wavelengths (Kirk 1994), and the satellite sensors detect the sum of their effects as if they were only caused by Chl, generating higher $\mathrm{Chl}_{\text {sat }}$ values. The greater concentrations of detritus and CDOM in the NW quadrant are caused by the summer cyclonic circulation that transports water from the Upper Gulf of California southward, in the northwestern part of the NGC (Álvarez-Borrego 2001). In general, in the Upper Gulf turbidity increases towards the northwest, with Sechii disk depths of $2 \mathrm{~m}$ in relatively deep waters and of $0.5-1 \mathrm{~m}$ near the Baja California coast. In the most turbid areas, seston values are $>130 \mathrm{mg} \mathrm{L}^{-1}$, with almost $100 \%$ of organic particles (García-de-Ballesteros and Larroque 1976).

Santamaría-del-Ángel et al. (1994a) reported that throughout the Gulf of California, the $\mathrm{Chl}_{\text {sat }}$ maxima occurred off the eastern coast, during winter upwelling events. In the NGC, however, winter $\mathrm{Chl}_{\text {sat }}$ maxima for the eastern quadrants showed no significant differences from those for the western quadrants. This could be attributed to the circulation in this region that carries water from one side of the NGC to the other relatively quickly, since it is the narrowest part of the gulf. A water parcel takes $\sim 10$ days to travel from one side to the other of the NGC, and phytoplankton biomass does not decrease significantly during the trajectory.

\section{ACKNOWLEDGMENTS}

MR Ramírez-León was granted a postgraduate scholarship by the National Council for Science and Technology (CONACYT, Mexico). FJ Ponce helped with the graphical design. The comments made by two anonymous reviewers helped to improve the manuscript. como ya fue reportado por Kahru et al. (2004) y ÁlvarezMolina et al. (2013) para todo el golfo. Hidalgo-González y Álvarez-Borrego (2004) y Kahru et al. (2004) reportaron que el ciclo estacional es el que tiene la mayor parte de la variación de $\mathrm{Chl}_{\text {sat }}$ y PF en el NGC. Desde hace varias décadas se sabe que el ciclo estacional de $\mathrm{Ch}_{\text {sat }}$ y PF está fuertemente determinado por los eventos de surgencias que los vientos del noroeste causan frente a las costas del continente durante invierno y la estratificación fuerte de verano con vientos del sureste (Álvarez-Borrego y Lara-Lara 1991).

Los valores altos de $\mathrm{Ch}_{\text {sat }}$ del CZCS fueron claramente mayores que los del SeaWiFS y Aqua-MODIS, de lo cual se podría inferir que ha habido una disminución de la biomasa fitoplanctónica de las décadas de los años setenta y ochenta a los años 2000, debido al deterioro del ecosistema pelágico del NGC por la falta de aporte del agua del río Colorado y sus nutrientes. Sin embargo, estas diferencias de $\mathrm{Chl}_{\text {sat }}$ se pueden deber a las diferencias en el diseño óptico de los sensores y no al cambio de las condiciones ambientales del NGC. Por ejemplo, Kahru et al. (2012) reportaron diferencias entre valores de $\mathrm{Chl}_{\text {sat }}$ deducidos de cuatro sensores (OCTS, SeaWiFS, Aqua-MODIS y MERIS), para el Sistema de la Corriente de California. En este estudio, las diferencias entre sensores se comprueban con los datos de $\mathrm{Chl}_{\text {sat }}$ de la cuenca de Guaymas, que es una región con valores muy altos de $\mathrm{Ch}_{\text {sat }}$ y PF, y donde no se tiene el efecto de falta de aporte de nutrientes por ríos. Los datos altos de $\mathrm{Chl}_{\text {sat }}$ del CZCS de la cuenca de Guaymas también fueron claramente mayores que los de los otros dos sensores, muy similar a lo que se observa para el NGC (fig. 5c). Por lo tanto, el CZCS sobreestima los valores de $\mathrm{Chl}_{\text {sat }}$ mayores que $0.5 \mathrm{mg} \mathrm{m}^{-3}$ por hasta $>5$ veces (fig. 5).

Las diferencias de $\mathrm{Ch}_{\text {sat }}$ y PF de verano entre el cuadrante NW y los otros cuadrantes fueron causadas por las mayores concentraciones de materia orgánica en el primero, como detritus o materia orgánica disuelta de color (MODC). Estos componentes ópticos del agua atenúan la luz fuertemente en longitudes de onda corta (Kirk 1994), y los sensores de satélite captan la suma de sus efectos como si se debieran sólo a la Chl, generando valores de $\mathrm{Ch}_{\mathrm{sat}}$ más altos. Las concentraciones mayores de detritus y MODC en el cuadrante NW se deben a la circulación ciclónica de verano que transporta agua del Alto Golfo de California hacia el sur, en el noroeste del NGC (Álvarez-Borrego 2001). En general, en el Alto Golfo la turbidez se incrementa hacia el noroeste con lecturas del disco de Sechii de $2 \mathrm{~m}$ en aguas relativamente profundas y de $0.5-1 \mathrm{~m}$ cerca de Baja California. En la zona más turbia, los valores de seston son de hasta $>130 \mathrm{mg} \mathrm{L}^{-1}$, con hasta cerca de 100\% de partículas orgánicas (García-deBallesteros y Larroque 1976).

Santamaría-del-Ángel et al. (1994a) reportaron que en todo el golfo de California, los valores máximos de $\mathrm{Chl}_{\text {sat }}$ se presentaron frente a la costa oriental, con eventos de surgencia de invierno. Sin embargo, en el NGC, los valores 


\section{REFERENCES}

Álvarez-Borrego S. 2001. The Colorado River estuary and Upper Gulf of California, Baja, Mexico. In: Seeliger U, Kjerfve B (eds.), Coastal Marine Ecosystems of Latin-America. Springer, Berlin, pp. 331-340.

Álvarez-Borrego S. 2002. Physical and biological linkages between the upper and lower Colorado Delta. Section Ecosystem Problems and Management at the US/Mexican Border. In: Rapport DJ, Lasley WL, Rolston DE, Nielsen NO, Qualset CO, Damania AB (eds.), Managing for Healthy Ecosystems. Lewis Publishers, Boca Raton, pp. 1077-1089.

Álvarez-Borrego S, Gaxiola-Castro G. 1988. Photosynthetic parameters of northern Gulf of California phytoplankton. Cont. Shelf Res. 8: 37-47. http://dx.doi.org/10.1016/0278-4343(88)90023-4

Álvarez-Borrego S, Lara-Lara JR. 1991. The physical environment and primary productivity of the Gulf of California. In: Dauphin JP, Simoneit B (eds.), The Gulf and Peninsular Province of the Californias. American Association of Petroleum Geologists, Tulsa, pp. 555-567.

Álvarez-Borrego S, Giles-Guzmán AD. 2012. Opal in Gulf of California sediments as a tool to estimate the vertical component of water exchange between the Gulf and the Pacific Ocean. Bot. Mar. 55: 161-168. http://dx.doi.org/10.1515/bot.2011.104

Álvarez-Borrego S, Rivera JA, Gaxiola-Castro G, Acosta-Ruíz MJ, Schwartzlose RA. 1978. Nutrientes en el Golfo de California. Cienc. Mar. 5(2): 53-71.

Álvarez-Molina LL, Álvarez-Borrego S, Lara-Lara JR, MarinoneMoscheto S. 2013. Annual and semiannual variations of phytoplankton biomass and production in the central Gulf of California estimated from satellite data. Cienc. Mar. 39(2): 217-230. http://dx.doi.org/10.7773/cm.v39i2.2189

Aragón-Noriega AE. 2014. Modeling the individual growth of the Gulf corvina, Cynoscion othonopterus (Pisces: Sciaenidae), using a multi-model approach. Cienc. Mar. 40(2): 149-161. http://dx.doi.org/10.7773/cm.v40i2.2410

Aragón-Noriega AE, Calderón-Aguilera LE. 2000. Does damming of the Colorado River affect the nursery area of blue shrimp Litopenaeus stylirostris (Decapoda: Penaidae) in the Upper Gulf of California? Rev. Biol. Trop. 48: 867-871.

Baumgartner TR, Christensen N. 1985. Coupling of the Gulf of California to large-scale interannual climatic variability. J. Mar. Res. 43(4): 825-848.

http://dx.doi.org/10.1357/002224085788453967

Behrenfeld MJ, Falkowski PG. 1997. Photosynthetic rates derived from satellite-based chlorophyll concentration. Limnol. Oceanogr. 42(1):1-20. http://dx.doi.org/10.4319/1o.1997.42.1.0001

Brusca RC, Findley LT, Hastings PA, Hendrickx ME, Cosio JT, Van der Heiden AM. 2005. Macrofaunal diversity in the Gulf of California. In: Cartron JLE, Ceballos G, Felger R (eds.), Biodiversity, Ecosystems, and Conservation in Northern Mexico. Oxford University Press, New York, pp. 179-203.

Carvajal M, Robles A, Ezcurra E. 2010. Ecological conservation in the Gulf of California. In: Brusca RC (ed.), The Gulf of California. Biodiversity and Conservation. University of Arizona Press, Tucson, pp. 219-250.

Cervantes-Duarte R, Mueller J, Trees CC, Maske H, ÁlvarezBorrego S, Lara-Lara JR. 2000. Euphotic depth, irradiance attenuation and remote sensing K490 in bio-optical provinces of the Gulf of California. Cienc. Mar. 26(4): 533-560. máximos de $\mathrm{Chl}_{\text {sat }}$ de invierno de los cuadrantes orientales no presentaron diferencias significativas con las de los cuadrantes occidentales. Esto puede deberse a que la circulación de esta región acarrea parcelas de agua de un lado al otro del NGC relativamente rápido, ya que es la más angosta del golfo. Una parcela de agua tarda $\sim 10$ días en llegar de un lado al otro del NGC y la biomasa fitoplanctónica no disminuye significativamente en la trayectoria.

\section{Agradecimientos}

MR Ramírez-León recibió una beca del Consejo Nacional de Ciencia y Tecnología (CONACYT, México) para sus estudios de maestría. FJ Ponce colaboró con el diseño gráfico. Los comentarios de dos revisores anónimos ayudaron a mejorar el manuscrito.

Cisneros-Mata MA. 2010. The importance of fisheries in the Gulf of California and ecosystem-based sustainable co-management for conservation. In Brusca RC (ed.), The Gulf of California. Biodiversity and Conservation. University of Arizona Press, Tucson, pp. 119-134.

Escalante F, Valdez-Holguín JE, Álvarez-Borrego S, Lara-Lara JR. 2013. Temporal and spatial variation of sea surface temperature, chlorophyll $a$, and primary productivity in the Gulf of California. Cienc. Mar. 39(2): 203-215. http://dx.doi/org/10.7773/cm.v39i2.2233

Galindo-Bect MS, Glenn EP, Page HM, Fitzsimmons K, GalindoBect LA, Hernández-Ayón JM, Petty RL, García-Hernández J, Moore D. 2000. Penaeid shrimp landings in the upper Gulf of California in relation to Colorado River freshwater discharge. Fish. Bull. 98: 222-225.

García-de-Ballesteros G, Larroque M. 1976. Elementos sobre la distribución de turbidez en el Alto Golfo de California. CalCOFI Rep. 18: 81-106.

Gaxiola-Castro G, Garcia-Cordova J, Valdez-Holguin JE, BotelloRuvalcaba M. 1995. Spatial distribution of chlorophyll $\alpha$ and primary productivity in relation to winter physical structure in the Gulf of California. Cont. Shelf Res. 15(9): 1043-1059. hmttp://dx.doi.org/10.1016/0278-4343(94)00071-T

Gendrop-Funes V, Acosta-Ruiz MJ, Schwartzlose RA. 1978. Distribución horizontal de clorofila $a$ durante la primavera en la parte norte del golfo de California. Cienc. Mar. 5(1): 71-89.

Giles-Guzmán AD, Álvarez-Borrego S. 2000. Vertical attenuation coefficient of photosynthetically active radiation as a function of chlorophyll concentration and depth in case 1 waters. Appl. Opt. 39(9): 1351-1358. http://dx.org/10.1364/AO.39.001351

Herrera-Cervantes H, Lluch-Cota SE, Lluch-Cota D, Gutiérrez-deVelasco G, Lluch-Belda D. 2010. ENSO influence on satellitederived chlorophyll trends in the Gulf of California. Atmósfera 23: $253-262$.

Hidalgo-González RM, Álvarez-Borrego S. 2001. Chlorophyll profiles and the water column structure in the Gulf of California. Oceanol. Acta 24(1): 19-28. http://dx.doi.org/10.1016/S0399-1784(00)01126-9

Hidalgo-González RM, Álvarez-Borrego S. 2004. Total and new production in the Gulf of California estimated from ocean color 
data from the satellite sensor SeaWIFS. Deep-Sea Res. (II) 51: 739-752. http://dx.doi.org/10.1016/j.dsr2.2004.05.006

Kahru M, Marinone SG, Lluch-Cota SE, Parés-Sierra A, Mitchell BG. 2004. Ocean-color variability in the Gulf of California: Scales from days to ENSO. Deep-Sea Res. (II) 51(1-3): 139-146. http://dx.doi.org/10.1016/j.dsr2.2003.04.001

Kahru M, Kudela R, Manzano-Sarabia M, Mitchell BG. 2009. Trends in primary production in the California Current detected with satellite data. J. Geophys. Res. 114(C02004): 1-7. http://dx.doi.org/10.1029/2008JC004979.

Kahru M, Kudela RM, Manzano-Sarabia M, Mitchell BG. 2012. Trends in the surface chlorophyll of the California Current: Merging data from multiple ocean color satellites. Deep-Sea Res. (II) 77-80: 89-98. http://dx.doi.org/10.1016/j.dsr2.2012.04.007

Kirk JTO. 1994. Light and Photosynthesis in Aquatic Ecosystems. Cambridge University Press, New York, $491 \mathrm{pp}$.

Lavín MF, Sánchez S. 1999. On how the Colorado River affected the hydrography of the Upper Gulf of California. Cont. Shelf Res. 19(12): 1545-1560. http://dx.doi.org/10.1016/S0278-4343(99)00030-8.

Lavín MF, Durazo R, Palacios E, Argote ML, Carrillo L. 1997. Lagrangian observations of the circulation in the northern Gulf of California. J. Phys. Oceanogr. 27(10): 2298-2305. http://dx.doi.org/10.1175/15200485(1997)027<2298:LOOTCI>2.0.CO;2

Lluch-Cota SE. 2000. Coastal upwelling in the eastern Gulf of California. Oceanol. Acta 23(6): 731-740. http://dx.doi.org/10.1016/S0399-1784(00)00121-3

Nieto-García E. 1998. Nutrientes en el norte del golfo de California durante condiciones estuarinas y antiestuarinas. MSc thesis, Centro de Investigación Científica y de Educación Superior de Ensenada, Baja California, $130 \mathrm{pp}$.

Platt T, Caverhill C, Sathyendranath S. 1991. Basin-scale estimates of oceanic primary production by remote sensing: The North Atlantic. J. Geophys. Res. 96(C8): 15147-15159. http://dx.doi.org/10.1029/91JC01118

Rodríguez CA, Flessa KW, Téllez-Duarte MA, Dettman DL, ÁvilaSerrano GA. 2001. Macrofaunal and isotopic estimates of the former extent of the Colorado River estuary, Upper Gulf of
California, Mexico. J. Arid Environ. 49(1): 183-193. http://dx.doi.org/10.1006/jare.2001.0845

Rojas-Bracho L, Taylor BL. 1999. Risk factors affecting the vaquita (Phocoena sinus). Mar. Mamm. Sci. 15(4): 974-989. http://dx.doi.org/10.1111/j.1748-7692.1999.tb00873.x

Rojas-Bracho L, Reeves RR, Jaramillo-Legorreta A. 2006. Conservation of the vaquita Phocoena sinus. Mamm. Rev. 36(3): 179-216. http://dx.doi.org/10.1111/j.1365-2907.2006.00088.x

Román-Rodríguez MJ. 2000. Estudio poblacional del chano norteño Micropogonias megalops y la curvina golfina Cynoscion othonopterus (Gilbert) (Pisces: Sciaenidae), especies endémicas del Alto Golfo de California, México. Instituto del Medio Ambiente y Desarrollo Sustentable del Estado de Sonora. Hoja de cálculo SNIB-CONABIO proyecto No. L298. CONABIO, México, $143 \mathrm{pp}$.

Santamaría-del-Ángel E, Álvarez-Borrego S, Müller-Karger FE. 1994a. The 1982-1984 El Niño in the Gulf of California as seen in coastal zone color scanner imagery. J. Geophys. Res. 99(C4): 7423-7431. http://dx.doi.org/10.1029/93JC02147

Santamaría-del-Angel E, Álvarez-Borrego S, Müller-Karger FE. 1994b. Gulf of California biogeographic regions based on coastal zone color scanner imagery. J. Geophys. Res. 99(C4): 7411-7421. http://dx.doi.org/10.1029/93JC02154

Santamaría-del-Ángel E, Álvarez-Borrego S, Millán-Núñez R, Müller-Karger FE. 1999. Sobre el efecto débil de las surgencias de verano en la biomasa fitoplanctónica del Golfo de California. Rev. Soc. Mex. Hist. Nat. 49: 207-212.

Valdez-Holguín JE, Gaxiola-Castro G, Cervantes-Duarte R. 1995. Primary productivity in the Gulf of California, calculated from the relationship between superficial irradiance and chlorophyll in the euphotic zone. Cienc. Mar. 21(3): 311-329.

Valdez-Holguín JE, Álvarez-Borrego S, Trees CC. 1999. Seasonal and spatial characterization of the Gulf of California phytoplankton photosynthetic parameters. Cienc. Mar. 25(4): 445-467.

Welch P. 1967. The use of the fast Fourier transform for the estimation of power spectra: A method based on time averaging over short, modified periodograms. IEEE Trans. Audio Electroacoustics AU-15: 70-73.

Received October 2014, accepted April 2015. 